\title{
Are Returns to Education on the Decline in Venezuela and Does Mission Sucre Have a Role to Play?
}

\author{
Naihobe Gonzalez*and Ruth Uwaifo Oyelere*†
}

June 29th, 2011

\begin{abstract}
Anecdotal evidence points to a falling standard of living for the educated in Venezuela. During this same period, President Hugo Chávez implemented several education reforms. We focus on a major university education reform known as Mission Sucre and its potential impact on returns to university education. First, we show that returns to education decreased significantly in Venezuela from 2002 to 2008. Subsequently, we explore the impact of the program on nonprogram participants and provide evidence that a substantial part of the falling returns at the tertiary level can be linked to Mission Sucre. Our results suggest that the reform created a negative externality on students who did not participate in the program, leading to a 2.7 percentage point decline in returns to university education for non-Mission Sucre students in the 23-28 age cohort.
\end{abstract}

(JEL classification: J2, J24, J38, I21, O12, O15. Keywords: Human Capital, Economic Impact, Rate of Return, Educational Economics)

*ndg2109@columbia.edu, Columbia University.

${ }^{\dagger}$ Corresponding author. ruth.uwaifo@econ.gatech.edu, School of Economics, Georgia Institute of Technology, 221 Bobby Dodd Way, Atlanta, GA 30332-0615. IZA, Bonn Germany. 


\section{Introduction}

After experiencing an economic downturn in 2002 and 2003, Venezuela's economy has boomed, in large part due to the rise in the price of petroleum, which increased four-fold between 2002 and 2007 to just under $\$ 100$ a barrel. In Venezuela, the oil sector accounts for about $90 \%$ of export earnings. Since 2004, the annual growth rate of Venezuela's gross domestic product has hovered between 8 and $18 \%$. However, contrary to what one might expect given an economic boom, anecdotal evidence suggests a trend in the opposite direction. "Things are worse than ever. You can't afford to live like you used to," said a middle-class resident of Caracas. Statements like this have become commonplace in Venezuela, especially among the more educated.

During this same period, President Hugo Chávez implemented a number of education reforms that may have had important labor market impacts and should be evaluated in light of this puzzling anecdotal evidence. Specifically, we focus on the implementation of a major university education reform and whether it led to a decline in returns to education in Venezuela. The reform program, known as Mission Sucre, was enacted in September 2003 to provide free mass tertiary education, eliminating screening and providing scholarships to the poor. Given the nature of the program's implementation, there are two potential economic channels that may have led to a decline in the returns to education.

The first is a simple demand-supply argument. The program, which in 2007 enrolled 336,499 students, dramatically increased the supply of skilled labor. All other things equal, returns to education will decline if the supply of labor increases and demand does not. Even if demand for skilled labor increases, as long as the increase in demand is less than the increase in supply, there is potential for a fall in the returns to education. The second possible channel is quality. There is evidence that education in the Mission Sucre universities is of low quality. If this is true, it follows that returns to education will decline when graduates from this program join the work force. A related issue is the decline in the quality of students receiving tertiary education. The Sucre Mission universities eliminated entrance exams, which applicants to public or private universities had to pass before entry into tertiary education. The removal of this quality screening mechanism implies that

the quality of students in Mission Sucre universities would be lower than elsewhere. In addition, the average quality of students who graduate from universities in Venezuela would decline over time, 
resulting in a fall in average returns to education.

Though these two channels could affect returns to education, the fall in returns to education resulting from a decline in the quality of education is harder to tease out due to the potential change in the selection into university education after the establishment of Mission Sucre universities. The absence of screening mechanisms at these universities would facilitate the entry of low ability individuals, making it difficult to disentangle the effect of an increase in low ability graduates in the labor market from the effect of a fall in the quality of tertiary education itself. We avoid this problem by not estimating the returns to education for either Mission Sucre graduates or all tertiary graduates in general. Rather, we focus on the labor market impact of this program on graduates from non-Mission Sucre universities. By focusing solely on non-Mission Sucre students, we do not address the full impact of the program, but rather focus on the externalities on non-Mission Sucre students. Given the scope of this university education expansion, short-term labor market externalities are an important area of research in their own merit.

A different reason for a decline in the returns to education during this period could be linked to the oil boom. Uwaifo (2006) shows that in Nigeria, another country heavily dependent on oil, returns to education have consistently declined during resource booms due to the high returns to rent-seeking activities during these booms and the greater ability of those with lower levels of education to move to rent-seeking jobs. This mechanism implies that the difference in income between low and high education individuals will be attenuated over the period of a boom, and hence the average returns to education will decline. However, there is also evidence of the importance of policy reforms and changes in institutional structures on returns. Uwaifo (2006) also highlights how democratic reforms and institutional change in Nigeria led to an increase in returns to education. Venezuela has undergone significant policy reforms over the last decade, and it is the link between a specific policy and returns to education that we provide evidence for in this paper.

First, we answer whether returns to education decreased in Venezuela after 2002. This exercise is particularly useful given Patrinos and Sakellariou (2006)'s result of increasing overall returns from 2000 to 2002. Using data from Venezuela's household survey for 2002, 2003, 2007 and 2008, we estimate simple Mincer (1974) wage equations. Though we do not control for ability, we do not worry about the potential endogeneity of the schooling variable in the wage equation, since our 
focus is not on obtaining a consistent estimate for schooling, but rather for the change in returns to education over time. This difference will be consistent as long as the effect of ability on the returns to education estimate does not vary over time for the sample considered. Prior to 2004, we expect the effect of ability in Venezuela to be constant. However, the implementation of an education policy in late 2003 has the potential of varying the impact of ability. We test for a possible change in the impact of ability, noting no such change between 2004 and 2008.

We find that the average returns to education declined by 3.1 percentage points over 20022008. This decline occurred for both men and women, though the decline for women was about one percentage point higher. Similarly, we note a decline in returns across states in Venezuela that varied significantly, between 1.2 and 5.6 percentage points. This variation across states is interesting and we explore it further in later parts of the study. Given our interest in potential changes in returns for the highly educated, we also compute the change in returns to different levels of education. We find that returns to all levels of education declined during this period, but that the return to university education fell by over 10 percentage points more than other levels.

Motivated by these preliminary findings, we move to evaluating the possible role of Mission Sucre on the significant decline in returns to university education. To provide evidence of the impact of Mission Sucre on non-Mission Sucre students, we exploit some of the unique features of the program to estimate the returns to education for different occupation categories we believe should be affected differently by the program. The results from these analyses provide suggestive evidence for the impact of Mission Sucre. For our main analysis, we compare the returns to university education and technical education. We focus on these particular levels of education because both are tertiary levels and are more likely to have similar general trends in returns. More importantly, Mission Sucre originally focused on only expanding university education. This allows us to classify those with university education as a treatment group and those with technical education as a potential control group. Identification is based on the premise that if Mission Sucre is responsible for the fall in returns to university education, we should only find significant changes in the returns to university education between 2007 and 2008. In contrast, we should find no change or insignificant changes in returns for those with technical education.

Using a difference in difference strategy, we estimate the impact of Mission Sucre between 2007 
and 2008 on returns to university education of non-Mission Sucre graduates. We focus on these two years because the first graduates from Mission Sucre entered the work force in 2008 and there was no other policy change between 2007 and 2008 that could affect returns to education differently across levels. If Mission Sucre had no impact, then any changes between 2007 and 2008 should be similar across university and technical education. If the program had an impact, on the other hand, then the difference in difference estimate should be significant. We focus on the youngest cohort in the work force (ages 23-28), where an impact is more likely to occur. We also conduct a pseudo difference in difference analysis using the years 2002 and 2003 to show that our difference in difference results are not driven by a trend effect. We find that Mission Sucre led to a 2.7 percentage point decrease in returns to university education among the 23-28 age cohort between 2007 and 2008. We do not find a significant impact between 2002 and 2003.

In our final analysis, we exploit the variation in states' shares of Mission Sucre students. Our hypothesis is that the larger the share of Mission Sucre students, the larger the negative externality and hence decline in returns to university education in the state. After finding the difference in returns to university education between 2007 and 2008 in each state, we regress this difference on the share of Mission Sucre students in university enrollment. We repeat this exercise for our technical education control group. As in our difference in difference strategy, if Mission Sucre explains the decline, and not a general trend or the oil boom, we expect a significant coefficient for university education and an insignificant coefficient for technical education. Our results are consistent with these expectations. We find that states with higher shares of Mission Sucre students had a larger decline in the returns to university education. Specifically, a 1\% increase in the share of Mission Sucre students led to a $0.4 \%$ decline in the returns to university education. We do not see a similar trend with respect to technical education.

Although we provide ample evidence of the impact of Mission Sucre on non-Mission Sucre students, we cannot state whether the noted effect of the program is driven solely by an excess supply of skilled labor, or a combination of the excess supply and other negative externalities of the program on nonparticipants 1 We suggest the effect is a response to a combination of the two factors, but

\footnotetext{
${ }^{1}$ For example, if there is a change in the perceived overall quality of university graduates in the labor market due to the existence of the program, employers may penalize all graduates with lower wages, despite the fact that they did not come from Mission Sucre universities and the quality of their education did not change. Although we do not have any evidence of this occurring in Venezuela yet, this is a possibility.
} 
cannot reject based on our results the possibility that it could be due solely to either one.

This paper contributes to the literature in three ways: first, it shows that after increases in returns to education between 2000 to 2002, returns declined again in Venezuela, despite the growth in GDP over the same period. Second, the paper adds to the literature that documents the impact of education reforms on labor market outcomes, such as returns to education. In particular, it addresses the short-term effects of a rapid and large expansion in access to university education. Finally, to the best of our knowledge, this is the first paper to document the potential impact of the Mission Sucre program.

The remainder of this paper is organized as follows: In the next section, we highlight some of the relevant literature. In section 3, we describe the data used. Section 4 focuses on our preliminary analysis on whether returns to education have declined over time in Venezuela. Section 5 focuses on possible explanations for the decline and section 6 provides empirical evidence in support of our hypothesized role of Mission Sucre. Conclusions and inferences are found in the last section.

\section{Literature Review}

Previous studies suggest that the rates of return to education in Venezuela had been declining since the 1970s. Using cross-sections from the Encuesta de Hogares por Muestreo household survey for the 1975 to 1984 period, Psacharopoulos and Steier (1988) find that the returns to schooling declined from about $13.7 \%$ to $11.2 \%$. They suggest that the changing returns to education are due to faster supply shifts of educated labor than corresponding demand shifts. However, they note that the decline over this decade was of only 2.5 percentage points, despite this period being characterized by rapid educational expansion. Psacharopoulos and Alam (1991) check for a continued downward trend in returns to education. Their results indicate that returns to education were relatively stable between 1984 and 1987, despite continued educational expansion. The interest in the trend in returns to education in Venezuela continued with Fiszbein and Psacharopoulos (1993), who find that returns to education had again declined, from $10.7 \%$ in 1987 to $9.6 \%$ in 1989.

Hence, between 1974 and 1989, returns to education fell by about 4.1 percentage points, quite a significant change. The consistent declining trend, however, changed in the 1990s. In a study estimating the returns to education in Venezuela for the period 1992 to 2002, Patrinos and Sakel- 
lariou (2006) note continued falling returns to schooling and educational levels until the mid-1990s, followed by increasing returns thereafter. In 1992, returns to education were $8.8 \%$, dropping to a low of $7.6 \%$ in 1996 . The following year, returns increased to $9.2 \%$, remaining fairly constant during the rest of the decade. In 2000, returns fell back to 8.0\%, increasing in 2001 and 2002 to $9.4 \%$ and 10.4\%, respectively. Patrinos and Sakellariou try to explain this trend in returns to education by focusing on changes in real wages and fluctuations in the returns to tertiary education. They argue that these changes in returns resulted from the effect of swings in economic activity in Venezuela on the demand and supply of education and skills. They highlight that the returns to tertiary education fluctuated sharply with the level of economic activity, whereas returns to primary and secondary education were relatively stable. The authors also mention emerging evidence that demand for educated labor was on the rise in Venezuela and that this might explain the increase in returns to tertiary education (and to some extent, secondary education) between 2000 and 2002.

These developments in returns to education in Venezuela from 2000 to 2002 are consistent with happenings in the 1990s in other middle-income Latin American counties such as Brazil, Mexico, Chile and Argentina (e.g., Kugler and Psacharopoulos, 1989; Lachler, 1998; Blom et al., 2001; Fiszbein et al., 2004 and Psacharopoulos et al., 1996). In these countries, the returns to secondary and tertiary education were also on rise, along with the overall return to schooling. Table A1 in the appendix summarizes some of the findings of these studies with respect to overall returns to education in Latin America. Returns to education in most Latin American countries were above $9 \%$, with most countries experiencing increasing returns to tertiary education. The difference with the Venezuelan story is that despite the expected increase in returns to tertiary education given the higher demand for educated labor noted by Patrinos and Sakellariou (2006), anecdotal evidence points to a falling standard of living for the educated over the last five years, which were marked by high economic growth.

Declining returns to education and volatility in returns to education as noted in the 1990s is not peculiar to Venezuela. Uwaifo (2006) finds that returns to education rose significantly in Nigeria following democratic reform, especially for those with tertiary education. This period of rising returns was preceded by a period of low, declining returns, documented in Oyelere (2010). Uwaifo (2006) provides evidence that returns to education respond to changing policies and institutional 
reform. Other authors have also tried to explain changing returns to education, whether rising or falling. For example, Fleisher et al (2005) explore the pace of increase in returns to schooling during the transition from planning to market economies across several Central and Eastern European countries, Russia, and China. They find that under post-economic reform and institutional changes consistent with a move towards a market economy, returns to education rose significantly in these countries. Similarly, Gorodnichenko and Sabirianova (2005) investigate why returns to schooling in Russia and Ukraine diverged over the same transition despite identical initial conditions and similar skill compositions of employment. They conclude based on semi-parametric analysis that lower demand for educated labor, more limited labor mobility, higher separation costs, and the larger role of trade unions in Ukraine played a role. De la Fuente and Jimeno (2008) also link low returns to education in Sweden to the country's compressed wage structure. These papers highlight changes in returns to education and important factors that could be responsible. In a similar vein, we focus on the trend in returns to education over the last six years in Venezuela and try to provide concrete evidence of what could have led to these changes.

\section{Data}

In this paper, we use consistent cross-sections of a government conducted household survey known as the Encuesta de Hogares por Muestreo, which is collected by the National Institute of Statistics of Venezuela (INE). It is the only survey in Venezuela that resembles the Living Standards Measurement Survey (LSMS) of the World Bank, but with a smaller variable coverage. The INE conducts this survey twice per year. Data are collected from randomly selected households all over the country. This data has been used by several researchers and is deemed reliable but as with most data from developing countries, this survey is not without some shortcomings like missing data for some variable observations 2 Also, though households are retained in the survey sample for six consecutive semesters in a rotating panel, the data suffers from very high attrition rates (41\% across three semesters and $90 \%$ across all six semesters in a similar sample of years, according to Hsieh et al., 2009) 3 We do not worry about the minor data issues highlighted above as they do not affect

\footnotetext{
${ }^{2}$ The missing data problem is minor in this data set. For example for a variable like level of education, about 0.16 of all observations did not answer the question.

${ }^{3}$ We do not exploit the panel aspect of this survey because of the rotating nature of the panel, the limited match to the years of data that we use, and its high attrition rate.
} 
our ability to derive consistent estimates of change in return. We primarily use data from the last six months of 2002 through the end of 2003, and from 2007 through the first six months of 2008 . To ensure that the data are comparable over time and across regions, current monetary values are deflated to 2007 base year prices. The Encuesta de Hogares por Muestreo is appropriate for the analysis, as it consists of detailed information on several demographic and economic indicators of all individuals within the household, including income, location, and other individual and household characteristics. An individual is the unit of observation in this data and the sub-sample of the data used in deriving returns to schooling and education levels consists of adults earning income (34\% of the sample). Table 1 is a summary of the main variables used in the analysis. We summarize these variables for all individuals in the sample and separately for earners 4

Table 1: Descriptive Statistics

\begin{tabular}{ccccccccc}
\hline \hline Variables & \multicolumn{3}{c}{ All } & \multicolumn{4}{c}{ Earners } \\
& $(1)$ & $(2)$ & $(3)$ & $(4)$ & $(5)$ & $(6)$ & $(7)$ & $(8)$ \\
& 2002 & 2003 & 2007 & 2008 & 2002 & 2003 & 2007 & 2008 \\
\hline Age & 26.33 & 26.68 & 28.14 & 28.45 & 36.71 & 31.79 & 32.66 & 38.12 \\
Female & 0.51 & 0.51 & 0.51 & 0.51 & 0.40 & 0.45 & 0.46 & 0.40 \\
Years of schooling & 6.70 & 6.77 & 7.38 & 7.46 & 9.00 & 7.86 & 8.36 & 9.69 \\
Completed primary & 0.31 & 0.31 & 0.37 & 0.38 & 0.48 & 0.39 & 0.44 & 0.54 \\
Completed secondary & 0.20 & 0.21 & 0.26 & 0.27 & 0.34 & 0.28 & 0.33 & 0.42 \\
Completed technical & 0.02 & 0.02 & 0.03 & 0.03 & 0.04 & 0.03 & 0.04 & 0.05 \\
Completed university & 0.03 & 0.03 & 0.04 & 0.04 & 0.07 & 0.05 & 0.06 & 0.08 \\
Log monthly income & & & & & 12.93 & 12.78 & 13.35 & 6.55 \\
Deflated monthly income & & & & & 600932 & 509351 & 791521 & 854714 \\
\hline \hline
\end{tabular}

\section{Preliminary Analysis: Estimating the Average Returns to Edu- cation}

The first question we address is whether the average returns to education have declined over time in Venezuela. To address this question, we estimate a Mincer (1974) standard wage equation. The

\footnotetext{
${ }^{4}$ In our wage analysis, we are restricted to the variables in the Encuesta de Hogares por Muestreo. One potential relevant variable not available in this data is employment sector (urban vs. rural). We do not worry too much about this missing variable since, even though it potentially could affect the estimated returns, it does not affect our derivation of a consistent estimate of the change in returns.
} 
Mincer wage equation is the basis of most of the basic empirical analysis in this paper. Equation 1 is a prototype of the equation we estimate using Ordinary Least Squares (OLS). We are interested in the estimate of the average returns to an additional year of schooling, $\beta_{1}$.

$$
\log \left(y_{i}\right)=\beta_{0}+\beta_{1} S_{i}+\beta_{2} X_{i}+\beta_{2} X^{2}+\beta_{3} D_{i}+\epsilon_{i}
$$

In equation $1, y_{i}$ is the wages/earnings of individual $i$, which could be either hourly or monthly. $X_{i}$ is the age of individual $i, S_{i}$ is the years of schooling of individual $i, D_{i}$ is a vector of all other possible exogenous control variables, including state dummies for individual $i$, and $\epsilon_{i}$ is the error term. 5

We estimate equation 1 separately for each year of data (2002, 2003, 2007, and 2008), using two measures of earnings (hourly earnings and monthly earnings). Table 2 presents basic estimates of equation 1. In columns (1), (3), (5), (7), the dependent variable is the log of monthly earnings, while in columns (2), (4),(6) and (8), the dependent variable is the log of hourly earnings. To answer whether returns have declined for both men and women, we also estimate the returns by gender separately. Table A2 in the appendix presents estimates of average returns to education by gender in 2002 and 2008, again using the two measures of earnings.

We begin by comparing our 2002 result from Table 2 to that of Patrinos and Sakellariou (2006), and find that the estimates are very similar. We do not expect identical estimates because we control for age and they control for potential experience (age-years of schooling-6) 6 We also use other controls like state dummies, which are not used by Patrinos and Sakellariou (2006). In addition, we use data from the second semester only, while the former use data from both semesters. The results highlight two main trends. First, returns to education in Venezuela have declined significantly over time, from $9 \%$ for every extra year of schooling in 2002 to $8.6 \%$ the next year, $7.1 \%$ in 2007 , and $6.1 \%$ in 2008. Between 2002 and 2008, there was a 2.9 percentage point decline in returns. We obtain a similar downward trend using hourly wages as the dependent variable, but with smaller magnitudes. Specifically, using hourly wages we find that returns to education fell from $8.0 \%$ in

\footnotetext{
${ }^{5}$ As we discuss later in this section, an OLS estimate of the returns to schooling from equation 1 may not be consistent, but is still adequate for our analysis under certain conditions.

${ }^{6}$ There is no consensus in the literature as to whether age or potential experience is more appropriate in a Mincer wage equation. We use age because it is more commonly used in the labor economics literature. However, a replica of Table 2 using potential experience can be found in our supplemental material available online.
} 
2002 to $7.7 \%$ in 2003, $6.7 \%$ in 2007, and 5.7\% in 2008 (a 2.3 point decrease between 2002 and 2008).

Whether using the log of hourly wage or monthly income, the differences in returns to education between 2002 and 2008 are statistically significant.

We also check for gender differences in the decline in returns (see table A2 in the appendix). The results in Table A2 provide evidence that the decline in returns was not gender specific. Returns to education declined by 2.6 percentage points for men and 3.4 percentage points for women 7 Although the fall in returns for women is slightly higher than for men over the period using log of monthly income, the fall is not statistically different for men and women when using log of hourly wage. More importantly, the gender analysis provides support that the fall was not substantially different across genders.

While the results in Table 2 suggest a decline in returns when comparing 2002 and 2008, it is possible to argue that the observed decline may only be a function of the data years chosen, given the suggested volatility in returns to education in Venezuela found in past literature (see Patrinos and Sakellariou (2006)). To provide evidence against this argument, we present a graph of estimated returns to education from 1994 to 2008 (see Figure A1) 8 This graph confirms that there has been some volatility in returns to education in Venezuela. However, a consistent downward trend in average returns to education can be noted from 2002 to 2008.

One important point that could be raised with regards to this decline in returns to education is that it could be driven by heterogeneity across states. If returns to education dropped drastically in only a few states, average returns to education might decline, but may still be high in some states. We investigate this possibility by estimating the basic Mincer equation by state for our four periods of data.

Figure 1 is a collection of maps of Venezuela showing the evolution in average returns to education from 2002 to 2008. The estimates used to make these maps can be found in Table A3 in the appendix. It is clear that there are statistical differences in the returns to education across some

\footnotetext{
${ }^{7}$ There is a potential selection bias in the estimates of returns to education for women because of the selection into labor force participation. This bias can be addressed using a Heckman correction model for selectivity. We do not present results with this correction because the focus of our paper is not on male-female differences or deriving a consistent estimate of returns, but rather deriving a consistent estimate of the change in returns.

${ }^{8}$ We obtain the Venezuela household survey data used to estimate returns to education from 1994 to 2005 from Professor Francisco Rodríguez's website [http ://frrodriguez.web.wesleyan.edu/data.htm] and use our data for the rest of the trend.
} 
Table 2: Basic Regression: Estimating Returns to Education

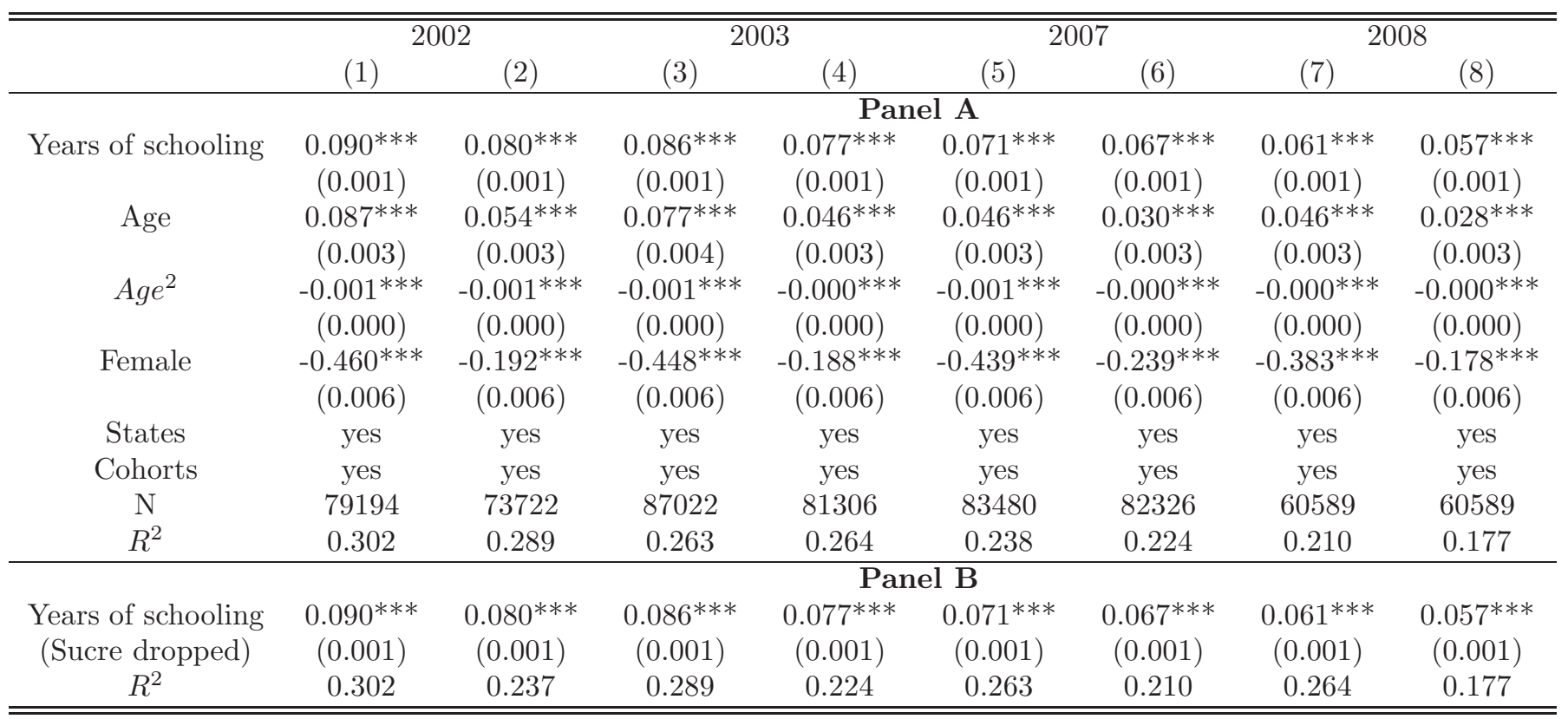

Note: The dependent variable in regressions (1), (3), (5), (7) is the log of monthly earnings, and in (2), (4),(6) and (8) is the log of hourly earnings. ${ }^{* * *}$ signifies statistical significance at the $1 \%$ significance level.

Estimates in Panel B are for the sample excluding all potential Sucre students while estimates in Panel A include the whole sample. The variables used in these analyses are years of school, gender, age, $a g e^{2}$, cohort dummies and state dummies.

states in Venezuela. For example, in 2002 the state of Aragua had an average return of 0.087, while Miranda, part of the Caracas metropolitan area, had a return of 0.11. In addition, the differences across states vary over time periods. Nevertheless, Figure 2 shows that returns to education have been declining across every state in Venezuela. This evolution is depicted by the changing colors over time. Further, the changes in the returns to education have been non-uniform across states. For example, the average return to education in the state of Aragua fell by 4 percentage points, from 0.087 to 0.047 . In contrast, the capital district only had a 1 percentage point decrease between 2002 and 2008 (from 0.073 to 0.063 ). The fact that every state in Venezuela experienced decreases, but of different magnitudes, suggests both national and state-specific effects may be taking place 9 The differential changes in returns across states are further explored later in the paper.

\footnotetext{
${ }^{9}$ Here we are assuming that our estimate of the change in returns in each state is consistent even though our estimate of returns may be biased.
} 


\section{Returns to education by state}

2002

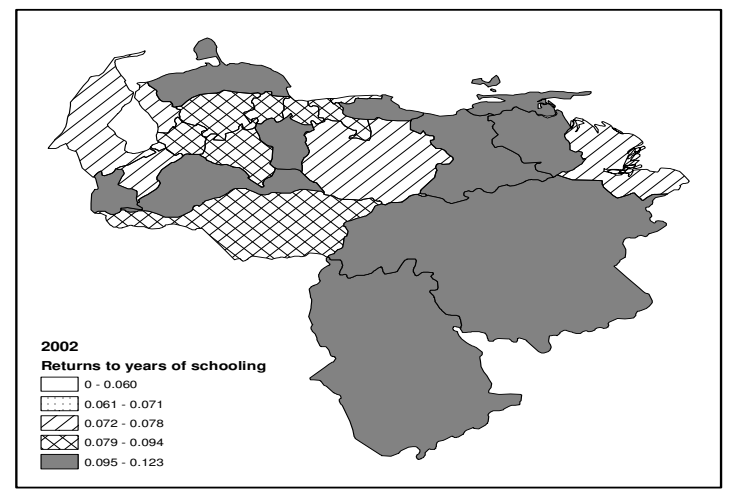

2007

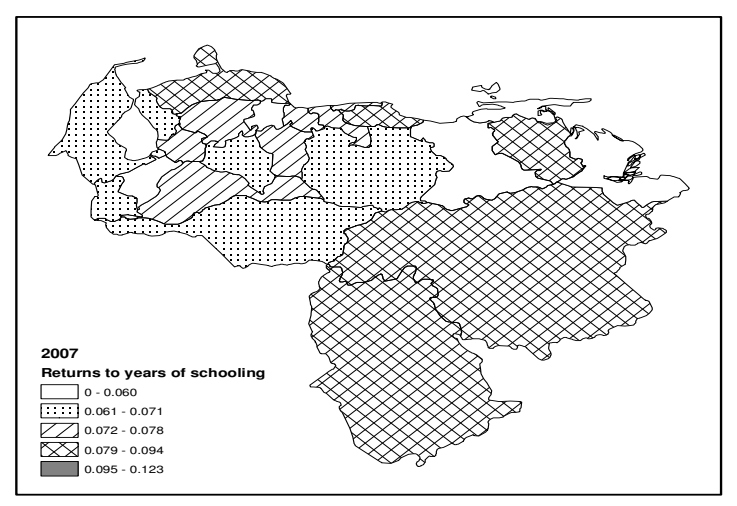

2003

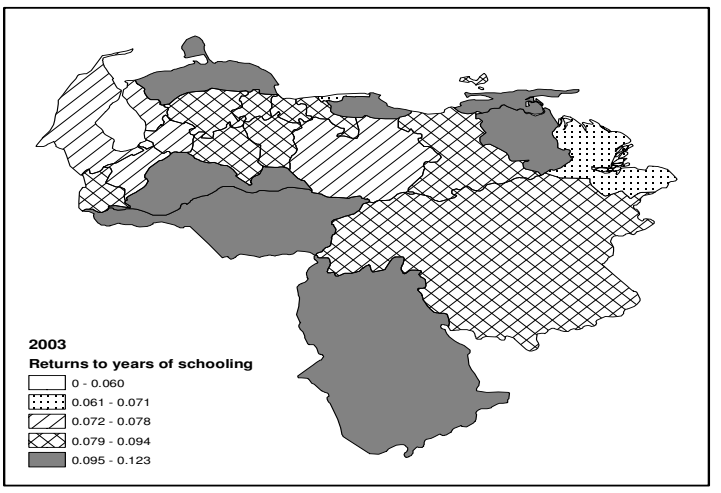

2008

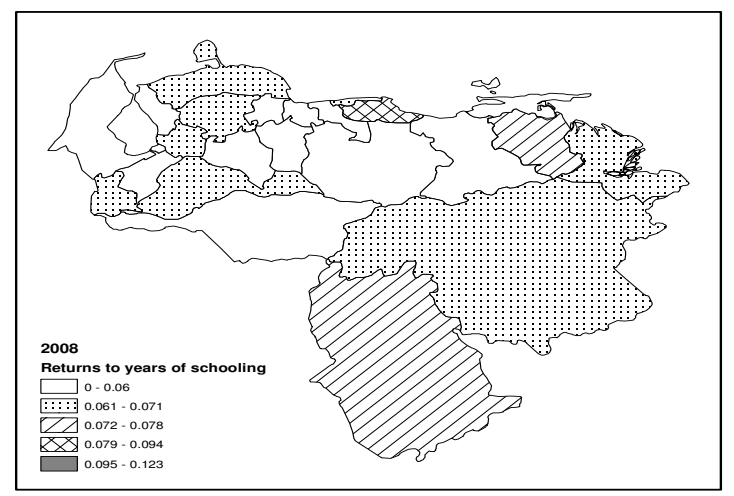

Figure 1: Evolution of Returns to Education across States in Venezuela 


\section{Addressing Potential Issues of Endogeneity}

Given the fact that we have not controlled for the endogenous nature of schooling in the wage regression, there is a possibility that our above estimates of average returns to education are not consistent. Since ability is correlated with educational attainment, not controlling for it could upwardly bias our estimates of returns. We searched for appropriate instruments for schooling in Venezuela but none could meet the necessary criteria for a good instrument. Given this constraint, we decide to continue with OLS instead of implementing an IV that could lead to even more biased estimates (see Staiger and Stock (1997) for potential issues of weak instruments).

We are not too concerned about the potential bias in the estimate of schooling using OLS for two reasons. First, there appears to be little evidence in Latin America of an upward bias in OLS estimates of returns to education (see for example Psacharopoulos and Velez's 1992 Colombia study). Some of the recent conclusions have been that the effect of ability on wages is negligible and the basic Mincerian earnings function is reliable. However, this finding is not peculiar to Latin America. Oyelere (2010) estimates returns to education in Nigeria, noting also no difference between the OLS and IV estimates. Given the aforementioned and other recent articles with similar trends (some mentioned in the literature review), it is quite likely that OLS average returns to schooling estimates may not be biased 10

The second and more important reason why we worry less about the possible inconsistency of the OLS estimates is because our focus in this paper is on differences or changes in average returns to education and not on returns to education per se. In other words, we are more interested in having a consistent estimate of the change in returns than obtaining consistent estimates of returns to education. The measure of the change in average returns to education between two time periods will be consistent as long as the potential bias in the OLS estimate of returns to education is time invariant. Without an intervention, there is no reason to believe the potential bias in OLS should be time variant. Ability is the primary missing variable that could create a bias in the OLS estimate. However, without an intervention or shock that shifts the ability distribution of workers, the impact of ability, if any, should not differ across years, meaning the potential bias in the estimate of $\beta_{1}$

\footnotetext{
${ }^{10}$ However, we acknowledge that there is a real possibility that estimates of returns could be upwardly biased and not consistent.
} 
should be time invariant. In the case of Venezuela, however, a policy intervention has the potential to cause a time varying ability bias post 2007 , which could make the estimate of the change in returns inconsistent. The possibility of an inconsistent estimate of the change in returns is especially relevant for tertiary education, which is the level directly affected by Mission Sucre.

We test whether this potential bias impacts our average returns to education estimates by dropping Mission Sucre students from the data and re-estimating the returns to education. We identify Mission Sucre students using two variables in the data. First a student must identify themselves as having a post secondary degree and must also identify themselves as having four years of university education. Table 2 Panel B captures these estimates. Note that there is no difference in the estimated returns with or without the Sucre Mission students. These results suggest a time-invariant ability bias as of 2008, which implies that our estimates of the change in returns to education should be consistent. One possible reason for this result is that Mission Sucre students may have still been too few in the sample to affect the average returns to education estimate 11 However, given the possibility that the potential bias may be more prominent when we consider the returns to tertiary education, for which the number of Sucre Mission students in the labor market is more relevant, and the potential issues of self-selection into Mission Sucre universities, for the remainder of the paper we restrict our focus on estimates for non-Mission Sucre students only. This is the sub-sample of students who we know did not pass through the Mission Sucre universities and for which ability bias should be time invariant. Unless indicated otherwise, in the regressions that follow we only estimate the returns to education for non-Mission Sucre graduates, rather than for the whole sample.

\section{Explanations for the Decline in Returns to Education}

Our preliminary analysis has led to two main facts. First, we know that the average returns to education have declined over time in Venezuela, and second, that the decline is not restricted to a particular gender or a particular state. The next question we focus on is what explains this decline.

There are two main possible reasons why returns to education have been on the decline in Venezuela despite the rise in returns from 2000 to 2002 and the economic boom between 2002 and

\footnotetext{
${ }^{11}$ It is worth nothing that as even more Sucre Mission students transition into the work force, the issue of a time variant ability bias will be more relevant for any research that focuses on labor market outcomes for the whole sample after 2009.
} 
2008. These explanations are based on specific events that have taken place in Venezuela over the last decade. The first reason is linked with a resource curse story. The second reason, which is the one we believe is more relevant for Venezuela, is the impact of education expansion programs, particularly Mission Sucre.

\subsection{The Resource Curse Explanation}

The first possible explanation for the fall in returns to education is the oil boom. Although this may seem surprising, during a resource boom there could be an increase in rent-seeking activities and opportunities to earn money not linked with specific skill sets or higher education. If beyond a threshold level of education there is a negative correlation between more education and rent-seeking prospects, one might notice a significant drop in the returns to tertiary education during a resource boom, as well as a drop to overall returns to education. Lane and Tornell (1996) and (1999) show that booms can increase rent seeking and lower growth rates. Similarly, Baland and Francois (2000) provide evidence from a model that suggests a resource boom can lower returns to activities that demand more human capital relative to rent seeking. Uwaifo (2006) also argues that the ability to shift to rent-seeking activities could be negatively correlated with education levels during an oil boom. Returns to education are attenuated as individuals with lower levels of education gain a higher earnings potential.

There is ample empirical evidence, like Gallagher (1991), that documents the more than proportionate rise in rents with increases in income or booms over the African continent. Furthermore, Africa is not the the only region where negative impacts of resource booms have been noted. Hilaire (1992) documents the labor market effects of an oil boom on Trinidad and Tobago. Baland and Francois (2000) highlight countries that have used most of the gains from booms to finance increased consumption and rent seeking, including Trinidad, Nigeria, Kuwait, the United Arab Emirates, Saudi Arabia, Venezuela, Mexico and Algeria. According to the authors, however, Venezuela, Mexico, and Algeria have done this to a lesser extent. It is thus plausible that returns to education have declined as a result of the oil boom of 2002 to mid-2008, which is similar to our period of analysis. We provide evidence for why the fall in returns to education cannot be explained solely by this resource boom. 


\subsection{The Supply-Demand and Quality Explanation}

The second possible explanation for the fall in returns to education is linked to two important factors that can affect returns to education. The first is quality and the second is the supply of labor. If the marginal productivity of skilled labor is linked to the amount of human capital acquired and determines wages, then a fall in the quality of education will lead to a fall in marginal productivity, wages, and the average returns to education. Even if quality of education drops for only a subsection of recent graduates, returns to education for all recent graduates could decline, assuming asymmetry in information between the employer and potential employee on the type of education received. In this scenario, employers could view the decline in quality of education for a subset of the population as a signal of future decline in quality for all graduates and offer lower wages to all future employees, in comparison to those hired in the past with a similar education signal. This effect could be viewed as a negative externality on all workers from the fall in the quality of education experienced by only a subset of the population 12

Similarly, assuming the skilled labor market is at an equilibrium, an increase in the supply of skilled labor would lead to a rightward shift in the labor supply curve. Without a commensurate increase in the demand for skilled labor, wages will fall. As long as similar changes do not occur for unskilled labor, the returns to education will decline. We believe the combination of a fall in quality and increase in supply of skilled labor generated by education programs implemented in Venezuela can explain a significant part of the decrease in returns to education in Venezuela from 2003 to 2008.

Since coming to power in 1999, President Hugo Chávez has developed a number of educational, anti-poverty, electoral, and military recruiting programs known as the "Bolivarian Missions." The educational component is comprised of three Mission programs-Robinson, Ribas, and Sucre-which provide primary, secondary and tertiary education, respectively, to the poor and marginalized segments of the population that have been denied access to education in the past. These programs are designed to feed into each other sequentially. According to government officials, approximately 2.7 million people have participated in this system of education programs. External analysis has confirmed this number, finding that about $10 \%$ of the population has participated 13 . In this paper

\footnotetext{
${ }^{12}$ This potential negative effect is compatible with a rational expectation framework.

${ }^{13}$ For more details on the Robinson and Ribas programs, see an earlier version of our paper in the IZA working paper series.
} 
we focus on the impact of Mission Sucre. Given the way Mission Sucre was implemented (discussed in the next section), we believe it should have stronger labor market impacts, relative to the other programs 14 Second, given claims of a falling standard of living for those with tertiary education and our interest in verifying and explaining these claims, we naturally focus on the program that could potentially affect the more educated.

\subsection{Mission Sucre}

Mission Sucre was enacted in September 2003 by President Hugo Chávez to provide free mass tertiary education, targeting the poor and marginalized. In the past, the absence of scholarship and loan programs, in addition to a centralized admissions process, had caused inequity in access, resulting in high-income families being over-represented in Venezuela's tuition-free public universities. Mission Sucre eliminated the centralized entrance exam, accepting all students who completed secondary education and giving special priority to students coming from the poorest sectors, those who graduated in or before 1990, and those who are unemployed or underemployed heads of households. The first cohort of students participated in a 6-8 month preparatory course, the Programa de Iniciación Universitaria (PIU), but this sole requirement was later eliminated in 2005. Mission Sucre created the Bolivarian University of Venezuela (UBV), with campuses in Caracas and Zulia and Bolívar states, as the primary medium for its program. The UBV shortened the traditional college curriculum from five years to three to four years, and provided scholarships to the poor. It also opened 11 experimental universities and 28 colleges around the country.

In 2004, about 1,000 provisional campuses were also founded with an aim of bringing higher education to the community level. Today, the UBV boasts over 1,700 satellite campuses all around the country. These campuses are known as Aldeas, which as an acronym stands for "Local Scopes of Alternative Socialist Education." Degrees offered in Mission Sucre campuses are limited to those deemed of national priority by the government and began with a select number in 2003. In 2005, the program expanded with 24 new majors and the construction of 37 new campuses in a number of states. By 2007, gross enrollment in tertiary education had increased to 41\%, from $29 \%$ in 1995 . In 2007, there were 612,000 students enrolled in regular public and private universities, 449,177

\footnotetext{
${ }^{14}$ Although Mission Sucre may have a played a more significant role in the fall in average returns to education, all the educational programs have the potential of creating a supply-demand mismatch, suggesting the fall in average returns cannot be attributed solely to any one program.
} 
enrolled in colleges and institutes, and 336,499 enrolled in Mission Sucre, making up 24\% of the total 15

One of the striking features of Mission Sucre universities is the significantly less stringent academic requirements for entry into these universities. In the past, all college-aspiring graduating high school students took a general exam like the SAT called the Prueba de Aptitud Académica (PAA), or Academic Aptitude Test. Private universities have additional screening criteria, while public university applicants had to go through the national admissions process, known as CNU-OPSU. The CNU-OPSU based admission on an academic index of high school grades and the PAA score, in addition to the student's region, graduation year and socioeconomic characteristics. However, Mission Sucre campuses, including the UBV (the program's flagship university), bypass this process. The only requirement for entry is a high school diploma. This lack of screening clearly leads to a reduction in the quality of the students admitted, which in turn has the potential of changing the distribution of ability among students at the tertiary level. We are only able to identify consistent estimates of the change in returns as long as any ability bias in our OLS estimates is not time variant. As mentioned earlier, we test for the introduction of time variant bias by 2008, noting no such trend.

Apart from the decline in the quality of students admitted, there is evidence that the quality of education in these Sucre universities and satellite campuses is much lower than other existing universities. One potential signal of this problem is that the program also shortens the traditional college curriculum from five years to three to four years. According to D'Elia and Cabezas (2008), "quality has been one of the most critical problems of the educational missions, which is reinforced by the absence of supervision and evaluation mechanisms." These authors document that the most reported complaints with Mission Sucre have been the low academic and pedagogic quality of the faculty and staff and their high rates of absenteeism and low rates of retention, often attributed to the irregularity of salary payments. Other concerns include failure to complete the established academic periods, high absenteeism rates of students, lack of teaching and support materials, and poor conditions of equipment and infrastructure. All of the above issues suggest a decline in quality (whether of students or the education they acquire), making a fall in returns to education due to a

\footnotetext{
${ }^{15}$ See D'Elia (2006).
} 
change in quality possible.

Apart from issues of quality, Mission Sucre led to a massive increase in skilled labor. In 2003, approximately 400,000 students enrolled in the program and began taking classes in the PIU program. Of these, about 196,000 completed the PIU program in 2005 and 53,000 enrolled in university programs. As mentioned above, tertiary enrollment has increased significantly in Venezuela. Over 300,000 students are now enrolled in Mission Sucre, which will transition into the work force. The transition of these students and the regular cohort of students from other universities into the work force will cause a rapid increase in the supply of college graduates. The first Sucre Mission alumni graduated in mid-to-late 200716 Our hypothesis is that the documented decrease in the returns to education can be explained in part by Mission Sucre, which led to a rapid expansion in skilled labor and a fall in the quality of tertiary education.

\section{Empirical Evidence for the Impact of Mission Sucre}

\subsection{Evidence from Differences Across Levels of Education}

Before searching for evidence of the impact of Mission Sucre, it is necessary to find out whether returns at the tertiary level of education have also declined. If the fall in returns to education is being driven in large part to Mission Sucre and not the oil boom, other programs, or a general trend, we should see differential changes in returns to education across levels. Differential changes are expected because Mission Sucre only creates an expansion in skilled labor at the tertiary level, and although other programs could also generate an expansion in the supply of labor at other levels, the elimination of screening mechanisms particular to Sucre Mission should lead to a greater decline in returns to education for those with university education. In addition, even if the returns to education have been trending downward in general, the fall in returns should be higher at the tertiary level if Mission Sucre has had an impact.

We estimate the returns to each level of education using equation $2 . \varsigma, \varpi,, \varphi$ and $\varrho$ are the estimates of the returns, or premium, to different levels of education for the four years of data available. We break down tertiary graduates into technical and university, where a technical degree is a three-year program akin to an associate's degree in the United States, and a university degree

\footnotetext{
${ }^{16}$ Some estimates claim that about 50,000 students had graduated by 2008 .
} 
refers to a traditionally five-year program equivalent to a bachelor's degree.

$$
\log (Y)=\theta+\gamma X+\delta X^{2}+\varrho p r i d u m+\varphi s e c d u m+\varpi t e c h d u m+\text { sunivdum }+\lambda_{2} Z+\varepsilon
$$

In this equation, $\mathrm{Y}$ is monthly earnings, $\mathrm{Z}$ is the matrix of all relevant control variables and year dummies, pridum is a dummy variable equal to one for all who completed primary school and 0 otherwise, secdum is a dummy variable equal to one for all who completed secondary school and 0 otherwise, techdum is a dummy variable equal to one for those who have postsecondary technical training and 0 for all others, and univdum is a dummy variable equal to one if an individual has at least a bachelor's degree. $\varsigma$ can be interpreted as the return to university education relative to those who have secondary education, while $\varpi$ is the return to technical education in comparison to those with secondary education.

We break down tertiary education into two groups due to our identification strategy, which we highlight in the coming sections. Mission Sucre originally offered only university education, and while in May 2005 it extended into technical education, the main focus of the program remains providing free university education 17 These differences in the timing of Mission Sucre universities and technical schools, along with the focus of Mission Sucre on university education, can create differential changes in returns for these two types of tertiary levels over time. In addition, our division of tertiary graduates into those with technical education and those with university education allows us to compare the payoff of each type of tertiary education in comparison to those with secondary education.

Given the similarities in our findings using both log of hourly earnings and log of monthly earnings and the decreased chance of measurement error in monthly earnings, we use log of monthly earnings as the dependent variable in the remainder of the paper. The result of the estimation of equation 2 is summarized in Table 3. As highlighted above, to avoid inconsistent estimates due to changes in ability bias at the tertiary level caused by the entrance of Mission Sucre graduates into the work force or by selection of individuals into Mission Sucre universities, we focus on the impact of the Mission Sucre program on those who did not select into the program.

\footnotetext{
${ }^{17}$ Enrollment in Mission Sucre technical education in 2005 was only $20.8 \%$ of total enrollment.
} 
Table 3 presents the estimates of the returns to each level of education for our four years of data. These estimates provide the payoff of obtaining the next level of education and allow us to compute the decline in payoffs to each level of education between 2002 and 2008. We find that the benefit of primary education declined by 11.8 percentage points; the returns to secondary education declined by 10.5 percentage points; the returns to technical education declined by 6.1 percentage points; and the returns to university education declined by 18.1 percentage points. This result highlights three issues. First, all levels experienced decreases in returns over time. Second, the largest decreases are found at each of the levels where the government instituted a concrete program to expand enrollment or increase access (primary, secondary, and university). Technical education, the only level that did not have a concrete government program intervention, had the lowest decline over time. As mentioned above, even though beginning in 2005 Mission Sucre began providing technical education, the focus of Mission Sucre is free university education, and it is at the university level that most of the program's expansion has taken place. More importantly, in our 2007 and 2008 data, there are no Mission Sucre technical graduates. Hence, falling returns at this level are independent of any program intervention. The change in returns at this level may instead capture a general downward trend in returns to education in Venezuela, while the changes at the other levels may capture both the trend effect and the impact of the respective programs. Note also that the payoff of primary and secondary education declined by similar percentage points. In contrast, the results from Table 3 show that the greatest fall in the returns to a level of education, in terms of percentage points, occurred at the university level 18 This finding is consistent with our expectations of significant quality and quantity effects from Mission Sucre. Although they may have also increased the supply of labor, the interventions at the primary and secondary levels did not change the criteria for entry, and hence should have a lesser human capital effect.

In addition, the significant and larger decline in returns at the primary and secondary levels in comparison to the technical education level raises doubts of these changes being a result of an oil boom. If this decline was linked with the oil boom explanation, we should not see significant

\footnotetext{
${ }^{18}$ Alternatively one could compute a percent decline in returns, comparing the two tertiary levels either between 2002 and 2008 or 2007 and 2008, and obtain the same finding. The change in returns at the university level is much higher than at the technical level. More importantly, over the 2007-2008 period, for which a decline is more relevant given the entrance of Mission Sucre gradates in the work force, the change in returns is negative at the university level, but a statistically insignificant increase at the technical level.
} 
Table 3: Basic Regression: Estimating Returns to Specific Levels of Education, 2002-2008

\begin{tabular}{ccccc}
\hline \hline & 2002 & 2003 & 2007 & 2008 \\
\cline { 2 - 5 } & $(1)$ & $(2)$ & $(3)$ & $(4)$ \\
\hline \multicolumn{4}{c}{ Returns to levels of education } \\
Primary Dummy & $0.270^{* * *}$ & $0.241^{* * *}$ & $0.193^{* * *}$ & $0.152^{* * *}$ \\
& $(0.009)$ & $(0.009)$ & $(0.008)$ & $(0.008)$ \\
Secondary Dummy & $0.233^{* * *}$ & $0.239^{* * *}$ & $0.155^{* * *}$ & $0.128^{* * *}$ \\
& $(0.010)$ & $(0.010)$ & $(0.009)$ & $(0.009)$ \\
Technical Dummy & $0.378^{* * *}$ & $0.342^{* * *}$ & $0.312^{* * *}$ & $0.317^{* * *}$ \\
& $(0.013)$ & $(0.014)$ & $(0.011)$ & $(0.011)$ \\
University Dummy & $0.774^{* * *}$ & $0.758^{* * *}$ & $0.664^{* * *}$ & $0.593^{* * *}$ \\
(Sucre dropped) & $(0.012)$ & $(0.012)$ & $(0.011)$ & $(0.011)$ \\
$\mathrm{N}$ & 79150 & 86970 & 82341 & 59756 \\
$R^{2}$ & 0.317 & 0.307 & 0.267 & 0.276 \\
\hline \hline
\end{tabular}

Note: Dependent variable: $\log$ of monthly income.

*significant at $10 \%$;* significant at $5 \%$; *** significant at $1 \%$.

The variables used in these analyses are: level of education variables, gender, age, age ${ }^{2}$, cohort dummies and state dummies.

declines at the lower levels of education 19 On the contrary, we should find the largest declines at both tertiary levels. Our results are instead consistent with program impacts, as noted above. We reiterate that we do not claim that the entire decrease in average returns to education can be attributed to the programs. The change in returns at the technical level is proof of a general trend effect. It is unrealistic to assume that over the span of seven years returns to education cannot trend upward or downward. In particular, the number of people with each of the levels of education has increased in Venezuela, and if labor markets do not produce similar increases in demand, then even without any policy or program returns may slowly decline.

In addition, this finding also raises doubts that the change in returns is driven entirely by a general trend. The past literature seems to suggest a decline in returns to education from the mid1970s to the mid-1990s. Based on this finding, it is possible to argue that the decline between 2002 and 2008 is just a continuation of that past trend, while the increase between 2000 and 2002 was simply an aberration. However, the small change in returns at the technical level over the same period, in comparison to all the other levels of education where policy reform took place, contradicts

\footnotetext{
${ }^{19}$ If results are driven by the oil boon, we should instead see an increase in returns to the primary and secondary levels, as explained earlier.
} 
a simple trend story. Further, the decline in the 1970s and early 1980s was not just a trend, but could be explained by education expansion. In addition, Patrinos and Sakellariou (2006) note that average returns stabilized in the mid-1990s and then began to rise after 2000, providing reasons for these changes, making it is less likely that the unexpected downward movement in returns to education is simply a trend effect. Although we cannot reject that part of the decline in returns may be linked with general trends, in the rest of the paper we present evidence of the role of Mission Sucre on declining returns, taking into account potential trending.

Another way of testing whether the changes are due to trends, rather than Mission Sucre, is to examine the change in returns to university education across states. Earlier we showed that the average returns to education changed differentially across states (see Figure 2). We re-estimate equation 3 by state for 2002, 2003, 2007, and 2008 (see Table A4 in the appendix for estimates) and focus on the changes in returns to university education versus technical education in our mapping analysis. Given the direct impact of Mission Sucre on the labor market for university graduates and the lack of impact on those with technical education by 2008, we use those with technical education as the control group in our analysis. Technical graduates also make a good control group because it is more likely that both types of tertiary education will face similar trends. The goal of Figure 2 is to capture both the transition in returns to university and technical education over time and the differences in changes across states. Comparing 2002 to 2008, Figure 2 highlights two main results. First, returns to university education fell across all states, but not uniformly. The returns to technical education also declined in most states, but in some states, the returns actually increased or remained constant. In addition, the magnitude of the drop in returns at the university level exceeds the drop in returns at the technical level. This result provides additional evidence for our hypothesis. Erratic changes, as noted for the control group, are less likely linked with a policy change, while a consistent drop in returns to university education across all states is more suggestive of a policy effect 20. In the next section we search for more specific evidence in support of the impact of Mission Sucre on returns to education.

\footnotetext{
${ }^{20}$ Based on the recommendation of a referee, we also checked for differential changes in returns from 2002-2008 using quantile regressions. Although the change in returns differed across the different income quartiles, the differences were small. Moreover, in all quantiles, bigger declines in returns were noted for university graduates compared to technical graduates (see the supplemental material available online for a summary of these results).
} 
Returns to higher education by state

2002

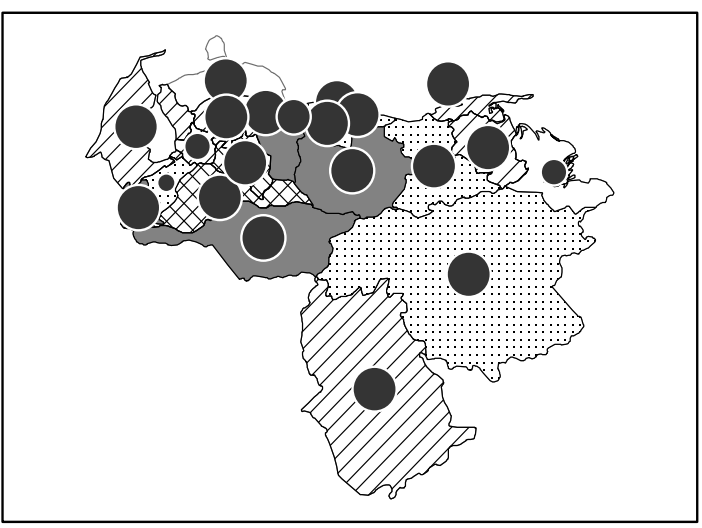

2007

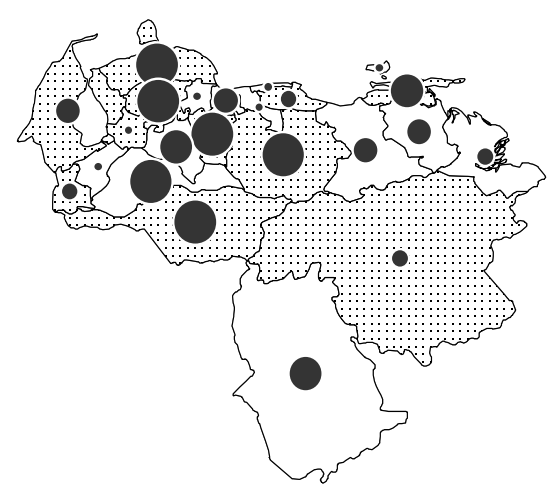

2003

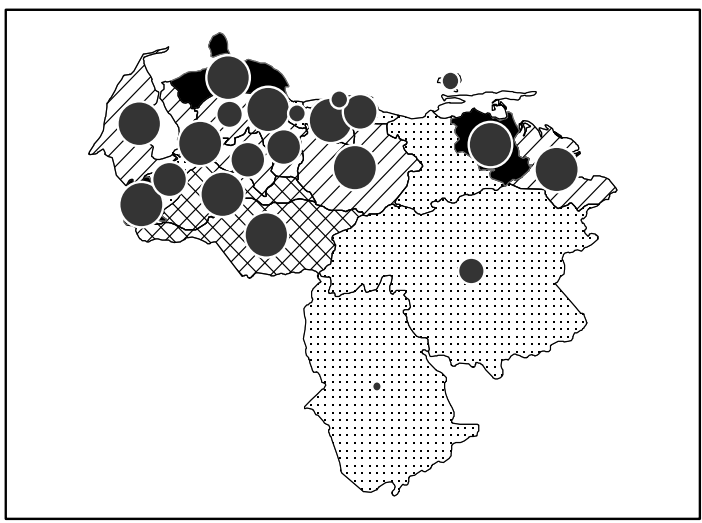

2008

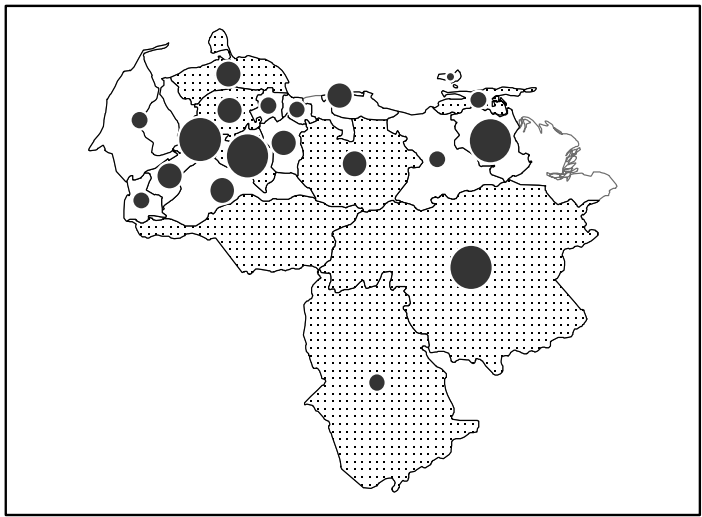

\section{Legend}

Returns to university education

Returns to technical education

\begin{tabular}{|c|c|}
\hline & $0.4780-0.6170$ \\
\hline & $0.6171-0.7680$ \\
\hline & $0.7681-0.8290$ \\
\hline & $.8291-0.89$ \\
\hline & $0.8901-1.000$ \\
\hline
\end{tabular}

- $0.1110-0.2380$

- $0.2381-0.2900$

$0.2901-0.3240$

$0.3241-0.3520$

$0.3521-0.5250$

Figure 2: Evolution of Returns to University and Technical Institutions Across States 


\subsection{Evidence from Occupational Categories}

In our search for evidence in support of our thesis, we consider differences in the average returns to university and technical education across occupational categories. One of the unique features of Mission Sucre is that students enrolled in the program can only choose from a select number of majors deemed by the government to be of national priority. At inception, Mission Sucre offered university degrees in the following fields: social communications, social and community management, telecommunications, ecological and environmental studies, and political and judicial studies. These fields were later extended, and in 2005, 24 new majors were added. The program fields now include agro-ecology, education, political studies, environmental management, health management, computer science, integral medicine and hydrocarbons.

We explore the uniqueness of the Mission Sucre fields in our attempt to identify whether the program led to a decline in returns to education, rather than a general trend effect or the oil boom. If the fall in returns is in response to an increase in the supply of graduates due to Mission Sucre, we should expect a greater market response in the occupations that the program focused on, in contrast to other fields without Mission Sucre students. To test this hypothesis, we divide all occupations into five categories: educators (a Mission Sucre major), other Mission Sucre occupations, management and other professionals (non-Mission Sucre majors), and elected officials and public administration employees (non-Mission Sucre majors). The potential problem we face with this analysis is that students may choose occupations different from their majors. Classifying individuals into occupational groups based on Mission Sucre fields may be noisy and prone to measurement error, leading to insignificant estimates. Despite these potential limitations, we estimate the average returns across these occupational groupings to see whether a pattern similar to what we expect emerges.

We estimate equation 3 for each of the occupational categories highlighted above. We focus on estimates for university and technical education in 2002 and 2008, and compute the changes between these two periods. We expect that for technical education, changes in returns will be minimal and where they exist, will be similar across occupations. In contrast, for university education we expect to see a decrease in returns in the Mission Sucre occupations, while for other occupation categories, we expect returns to be non-decreasing. Table 4 summarizes the results of this analysis. 
The results in Table 4 are consistent with our thesis. For the non-Mission Sucre students in occupational categories not targeted by Mission Sucre, we note a similarity in the direction of change in returns to education at both the technical and university level. Specifically, the "All Others" category shows no significant differences in the returns to technical or university education over the 2002-2008 period. For the management category, we note an increase in returns at both the technical level (10.6 points) and university level (15.9 points). In contrast, for non-Mission Sucre students in occupations targeted by the program we note differences in trends between the technical and university levels. For example, looking at the Mission Sucre affected occupations, we note a rise in the returns to technical education of about 9 percentage points and a drop of 3.4 points at the university level. For the other Mission Sucre affected occupations, we note no change in the returns to technical education, while we see a 4.8 percentage point drop in returns to university education 21 These results provide additional evidence that Mission Sucre had an impact on returns to university education. Note that only occupations affected by the program experienced a substantial drop in returns, and only at the university level. Interestingly, returns for university graduates were rising or stable for all other professions.

\section{$7 \quad$ Difference in Difference Strategy}

In the next two sections, we present our most compelling evidence for the impact of Mission Sucre on returns to tertiary education. We explore the fact that Mission Sucre focused solely on university education at its inception, even though both technical and university education are tertiary levels. Although the program implemented technical education programs in 2005, we argue that technical education is a good control for our analysis for three reasons.

First, technical degrees, whether Mission Sucre or regular, continued to be three years in duration. This is in contrast to university education, where the length was shortened in the Mission Sucre universities, resulting in a potential source of falling quality. Second, technical schools did not have the significant supply constraint that universities had due to difficult screening exams and other entry criteria. Though technical schools have an entrance exam, this exam is not viewed as a significant constraint, unlike the university entrance exams. As a result, we do not expect as great of

\footnotetext{
${ }^{21}$ The decline in the returns to university education between 2002 and 2008 for the Mission Sucre occupations are not significantly different at the $95 \%$ level but could be due to the potential noise in this analysis, as highlighted above.
} 
Table 4: Basic Regression: Differences in the return to Technical and University Education level by Occupation

\begin{tabular}{ccccccc}
\hline \hline & \multicolumn{3}{c}{ Technical } & \multicolumn{4}{c}{ University } \\
\cline { 2 - 7 } & 2002 & 2008 & Diff & 2002 & 2008 & Diff \\
\hline Educators & $0.286^{* * *}$ & $0.376^{* * *}$ & $0.090^{*}$ & $0.639^{* * *}$ & $0.605^{* * *}$ & -0.034 \\
& $(0.039)$ & $(0.034)$ & & $(0.029)$ & $(0.029)$ & \\
Other Sucre Mission occupations & $0.237^{* * *}$ & $0.232^{* * *}$ & -0.005 & $0.573^{* * *}$ & $0.525^{* * *}$ & -0.048 \\
& $(0.039)$ & $(0.032)$ & & $(0.030)$ & $(0.026)$ & \\
Management \& Other Professionals & 0.052 & $0.158^{* * *}$ & $0.106^{* *}$ & $0.218^{* * *}$ & $0.377^{* * *}$ & $0.159^{* * *}$ \\
& $(0.040)$ & $(0.030)$ & & $(0.038)$ & $(0.027)$ & \\
Elected Officials \& Public Admin. Employees & 0.041 & 0.223 & 0.182 & 0.210 & $0.354^{* * *}$ & 0.144 \\
& $(0.144)$ & $(0.135)$ & & $(0.110)$ & $(0.096)$ & \\
All others & $0.290^{* * *}$ & $0.280^{* * *}$ & -0.010 & $0.436^{* * *}$ & $0.444^{* * *}$ & 0.008 \\
& $(0.018)$ & $(0.015)$ & & $(0.029)$ & $(0.025)$ & \\
\hline \hline
\end{tabular}

Note: Dependent variable: log of monthly income significant at $10 \%$; ** significant at $5 \%$; *** significant at $1 \%$.

Each of the estimates comes from a separate regression. The variables used in each analysis are indicator variable for primary education, secondary education, technical education, university education, gender, age, $a g e^{2}$, cohort dummies and state dummies.

a decline in the quality of students at Sucre Mission technical institutes, in contrast to the Mission Sucre universities. In addition, as mentioned above, Mission Sucre is primarily focused on university education, and almost $80 \%$ of Mission Sucre students are in university programs. Third and most importantly, the Mission Sucre technical programs began in 2005, so graduates from this program would have only graduated and entered the work force beginning fall 2008. Since the data we use is from the first semester of 2008, Sucre Mission technical students had not yet graduated and entered the work force, making them an appropriate control group. Based on these three reasons, any change in returns to technical education over this period can be attributed to other factors affecting returns to tertiary education (for example, a general trend or oil boom). It is fair to assume that such trends are similar across university and technical education given that both are higher levels of education.

To be as precise as possible, we estimate the returns to technical and university education using equation 2 for students who did not pass through Mission Sucre universities and are in the 23-28 age group. This age group is the most likely to be directly impacted by the policy because they are new entrants into the work force, and Mission Sucre should most affect the supply of labor at the 
entry level. Hence, wages of older cohorts already in the work force are less likely to be affected significantly. Returns are estimated for the year 2007 and 2008 at the technical and university level and a difference in difference in returns is computed, where those with technical education are the control group. Assuming no other change that could affect university education solely between 2007 and 2008, our difference in difference estimation captures the direct immediate effect of Mission Sucre on returns to university education. As stated earlier, we focus on the period following the entrance of Mission Sucre graduates into the work force and compare it to the period immediately preceding entrance. To confirm that we are not just capturing differences in trends for university and technical graduates, we perform a similar pseudo analysis using the 2002 and 2003 returns to university and technical education. The results are summarized in Table 7.

Panel A presents the pseudo analysis and Panel B presents the real analysis. Note that the difference in difference estimate from the pseudo analysis is not significantly different from 0 , while the same analysis comparing 2007 and 2008 suggests that Mission Sucre led to a 2.7 percentage point decline in the returns to university education for the 23-28 age cohort 22 As mentioned earlier, identification is achieved because even though each estimate of the return to education may not be consistent, the change in returns and difference in difference estimate will be. We present the difference in difference estimates using both the whole sample and the sub-sample that excludes all Mission Sucre graduates and possible Mission Sucre graduates 23

\section{Identification Using a Regression Analysis}

As a final robustness check on the impact of Mission Sucre on returns to university education, we exploit the differences in program impact across states. While Sucre Mission had a presence in all states, we know that the number of students enrolled in the program differed. If the supply-demand

\footnotetext{
${ }^{22}$ In the previous section we mention that there is some evidence that many Mission Sucre graduates belong to the 29-40 age cohort. The estimate of the impact of the program for the 23-28 age cohort is thus a lower bound on the total program impact.

${ }^{23}$ We are able to identify Mission Sucre graduates because they have four years of university education and a completed university degree, while other university graduates have five years of university education. Potential Mission Sucre graduates are those who are university graduates but did not indicate the number of years of university education. Many of these students may not have participated in Mission Sucre, but so as to avert any selection bias from including Mission Sucre observations, we exclude these students from the analysis. The observations dropped because of lack of information on years of university education are less than $0.5 \%$ of the $23-28$ year old sample. Our results are not dependent on this exclusion, and we obtain very similar estimates using the full sample.
} 
Table 5: Estimating the Impact of Mission Sucre on returns: Difference in Difference Analysis

\begin{tabular}{|c|c|c|c|c|c|c|}
\hline & 2002 & 2003 & Difference & 2007 & 2008 & Difference \\
\hline \multirow{4}{*}{$\begin{array}{l}\text { Non-Sucre University } \\
\text { (Age 23-28) } \\
\text { Technical } \\
\text { (Age 23-28) }\end{array}$} & (1) & $(2)$ & $(3)$ & $(4)$ & $(5)$ & $(6)$ \\
\hline & & Panel A & & & Panel B & \\
\hline & $\begin{array}{c}0.702^{* * *} \\
(0.033)\end{array}$ & $\begin{array}{c}0.670 * * * \\
(0.032)\end{array}$ & -0.032 & $\begin{array}{c}0.624^{* * *} \\
(0.029)\end{array}$ & $\begin{array}{c}0.567^{* * *} \\
(0.027)\end{array}$ & $-0.057 * *$ \\
\hline & $\begin{array}{c}0.371^{* * *} \\
(0.024)\end{array}$ & $\begin{array}{c}0.345^{* * *} \\
(0.024)\end{array}$ & -0.026 & $\begin{array}{c}0.341^{* * *} \\
(0.021)\end{array}$ & $\begin{array}{c}0.311^{* * *} \\
(0.021)\end{array}$ & -0.03 \\
\hline Difference & & & -0.006 & & & $-0.027 * *$ \\
\hline $\mathrm{N}$ & 13019 & 13980 & & 13071 & 9467 & \\
\hline$R^{2}$ & 0.231 & 0.223 & & 0.193 & 0.213 & \\
\hline
\end{tabular}

Note: Dependent variable is log of monthly income in each regression. Estimate used in diff-in diff analysis are returns to technical and university levels of education for affected age group. In the regressions we used to derive the returns to technical and university education, we controls for primary education, secondary education, technical education, university education, gender, age, $a g e^{2}$, cohort dummies and state dummies. *significant at $10 \%$; ${ }^{* *}$ significant at $5 \%$; ${ }^{* * *}$ significant at $1 \%$.

and quality arguments we highlighted above are applicable, then in states with higher enrollment impacts, there should be larger increases in the supply of skilled labor, which should lead to higher declines in the returns to education. Similarly, in states with higher Mission Sucre enrollment impacts, the decline in the quality of education and students should be more acute, leading to a more severe decrease in the returns to education. Of course, if individuals can move across states with ease after graduation, this argument will be less tenable. In the Venezuelan case, internal migration rates are low and chiefly eastward, from the far northwest (Tachira, Merida, and Trujillo) to Caracas 24 To test for a relationship between the enrollment share of Mission Sucre students in a state and the fall in returns to education across states, we again focus on the returns to university education and use the returns to technical education as a control group or placebo analysis. We first estimate the returns to education across each state in Venezuela for the first semester of 2007 and the first semester of 200825 Next we calculate the percent of Mission Sucre students in the population in each state and the change in returns to education in each state for the two periods.

\footnotetext{
${ }^{24}$ According to the CIA Fact Book, Venezuela has -0.42 migrant(s)/1,000 population (2009 est.), a low figure.

${ }^{25}$ We do not restrict ourselves to the $23-28$ age cohort because the sample size of this cohort is very small for some states, leading to noisy estimates. However, we are faced with a trade off, because if we focus on returns to university education for all cohorts, rather than recent graduates, the estimates of the impact of shares of Mission Sucre students on changes in returns may also be noisy and insignificant. Hence, our estimates may exhibit the predicted trend, but the coefficients may be insignificant.
} 
Finally, we run a simple OLS regression on equation 3.

$$
\beta_{i, t}-\beta_{i, t-1}=\lambda X_{i}+\epsilon
$$

Where $\beta_{i, t}$ is the return to university education in state $i$ in 2008 and $\beta_{i, t-1}$ is the return to university education in state i in the first semester of 2007.

We use the share of Mission Sucre students in a state's population in 2007 as a proxy for the share of Mission Sucre students among enrolled tertiary students in a state. We cannot use the proportion of tertiary education students enrolled in Mission Sucre because there is no data available on total enrollment in tertiary education disaggregated by state. Given the imperfection of this proxy, we re-estimate equation 3 with two other proxies as a robustness check. Our first alternative proxy is the proportion of Mission Sucre students to students above the age of 15 in each state, and the second is the share of Mission Sucre students out of all high school students by state. The first of our alternative proxies is based on the premise that most university students are above the age of 15 , so restricting the population of students above this age should increase the precision of the proxy. Although the population of students above 15 in a state is strongly correlated with the enrollment in tertiary education in the state, however, students above 15 could still be in high school. In this case, the proxy would be downward biased in comparison to the real share. For the last proxy, since high schools feed directly into tertiary education, the population of high school students across states should have a distribution similar to tertiary enrollment. However, to the extent that many students do not attend college, this proxy could also be downward biased in comparison to the true Mission Sucre share in a state. The summary of these shares are presented in Table A5 in the appendix.

We select the first semester of 2007 as the pre-period because data was collected just before entrance into the work force of any Mission Sucre students (the first round graduated in mid-2007). In addition, we choose 2008 and not fall 2007 as the comparison period to maximize capture of new entrants into the work force, leaving some room for transition into the work force, which can take a few months. $X_{i}$ is the share of Mission Sucre students in the population in state i. We then estimate equation 3 replacing the change in returns to university education for each state with the change in returns to technical education for our control group analysis. We expect that $\lambda=0$ for this analysis, while $\lambda<0$ for the analysis using university education because a higher share of Mission 
Sucre student enrollment in a state should lead to a greater decline only in returns to university education. We do not include a constant term in this estimation because we believe that over a short period like 2007-2008, any significant change in returns should be linked with the impact of Mission Sucre students' school-to-work transition. This assumption would be flawed if there was another shock or policy change that coincided with this period and could affect returns to tertiary education, but there was none. This modeling strategy is of course less tenable in the long run. To check for a long run relationship, we estimate equation 4 .

$$
\beta_{i, 2008}-\beta_{i, 2002}=\alpha+\gamma X_{i}+\epsilon
$$

Where beta can be either the return to university or technical education.

The problem with this longer term analysis is the potential endogeneity of $X$, since the change in returns over six years could be driven by several factors, including general trends and oil booms, that could potentially be correlated with the share of enrollment in Mission Sucre across states. For example, states with higher shares of Mission Sucre students might be states that embrace Hugo Chávez's policies more readily and intervene more in the labor market, which could lead to an exogenous decline in returns to education over time. Hence, the impact of Mission Sucre could be overstated. One simple way of verifying whether this possible concern for endogeneity is valid is to check the estimate of $\gamma$ when we use the change in returns to technical education between 2002 and 2008. If there is a significant relationship between the shares and the changes in returns to technical education between 2002 and 2008, then the endogeneity of $X$ is more likely. However, if there is no relationship, then it is less likely that this variable would lead to an inconsistent estimate of the effect. We estimate $\gamma$ in a regression with and without a constant term in this longer term analysis. In this case, including a constant is the correct specification because of the possibility that the change in returns to education over six years (2002-2008) could be linked to factors like the oil boom or general population trends.

Table 6 summarizes the results from the estimation of equations 3 and 4 for different periods. We again focus on estimates for only non-Mission Sucre students. In Panel A we use the percentage of a state's population that are Mission Sucre students, in Panel B we use the percentage of a state's student population over the age of 15 that are Mission Sucre students, and in Panel C our proxy is 
Table 6: Basic Regression: Estimating the Impact of the Share of Mission Sucre Students in a State on Changes in Return

\begin{tabular}{|c|c|c|c|c|c|c|c|c|}
\hline \multicolumn{9}{|c|}{ Panel A: Percent Sucre Mission Enrollment Based on Total Population } \\
\hline & \multicolumn{2}{|c|}{$2008-2007(1)$} & \multicolumn{4}{|c|}{$2008-2002$} & \multicolumn{2}{|c|}{$2008-2007$} \\
\hline & University & Technical & University & Technical & University & Technical & University & Technical \\
\hline & Treatment & Control & Treatment & Control & Treatment & Control & Treatment & Control \\
\hline & $(1)$ & $(2)$ & $(3)$ & $(4)$ & $(5)$ & $(6)$ & $(7)$ & $(8)$ \\
\hline \multicolumn{9}{|c|}{ Panel A: Percent Sucre Mission Enrollment Based on Total Population } \\
\hline$\%$ Enrollment & $\begin{array}{c}-0.052^{* * *} \\
(0.015)\end{array}$ & $\begin{array}{l}-0.006 \\
(0.022)\end{array}$ & $\begin{array}{c}-0.086^{* *} \\
(0.044)\end{array}$ & $\begin{array}{l}-0.003 \\
(0.037)\end{array}$ & $\begin{array}{c}-0.152^{* * *} \\
(0.015)\end{array}$ & $\begin{array}{c}-0.044^{* * *} \\
(0.013)\end{array}$ & $\begin{array}{l}-0.019 \\
(0.014)\end{array}$ & $\begin{array}{c}0.002 \\
(0.011)\end{array}$ \\
\hline Constant & NA & NA & $\begin{array}{c}-0.102 \\
(0.063) \\
\end{array}$ & $\begin{array}{r}-0.063 \\
(0.048) \\
\end{array}$ & NA & NA & $\mathrm{NA}$ & NA \\
\hline$R^{2}$ & 0.325 & 0.004 & 0.175 & 0.000 & 0.775 & 0.325 & $\overline{0.064}$ & 0.001 \\
\hline $\mathrm{N}$ & 23 & 23 & 23 & 23 & 23 & 23 & 23 & 23 \\
\hline \multicolumn{9}{|c|}{ Panel B: Percent Sucre Mission Enrollment Based on Students Above Age 15} \\
\hline$\%$ Enrollment & $\begin{array}{c}-0.004^{* * *} \\
(0.001)\end{array}$ & $\begin{array}{c}-0.000 \\
(0.002)\end{array}$ & $\begin{array}{c}-0.006^{* *} \\
(0.003)\end{array}$ & $\begin{array}{c}0.000 \\
(0.002)\end{array}$ & $\begin{array}{c}-0.011^{* * *} \\
(0.001)\end{array}$ & $\begin{array}{c}-0.003^{* * *} \\
(0.001)\end{array}$ & $\begin{array}{c}-0.002 \\
(0.001)\end{array}$ & $\begin{array}{c}0.000 \\
(0.001)\end{array}$ \\
\hline Constant & $\mathrm{NA}$ & NA & $\begin{array}{c}-0.120^{* *} \\
(0.056)\end{array}$ & $\begin{array}{c}-0.072^{*} \\
(0.041)\end{array}$ & NA & NA & $\mathrm{NA}$ & \\
\hline$R^{2}$ & 0.336 & 0.000 & 0.185 & 0.002 & 0.754 & 0.260 & 0.073 & 0.001 \\
\hline $\mathrm{N}$ & 22 & 22 & 22 & 22 & 22 & 22 & 22 & 22 \\
\hline \multicolumn{9}{|c|}{ Panel C: Percent Sucre Mission Enrollment Based on High School Students } \\
\hline$\%$ Enrollment & $\begin{array}{c}-0.001^{* * *} \\
(0.000)\end{array}$ & $\begin{array}{l}-0.000 \\
(0.001)\end{array}$ & $\begin{array}{c}-0.002^{* *} \\
(0.001)\end{array}$ & $\begin{array}{l}-0.000 \\
(0.001)\end{array}$ & $\begin{array}{c}-0.004^{* * *} \\
(0.000)\end{array}$ & $\begin{array}{c}-0.001^{* * *} \\
(0.000)\end{array}$ & $\begin{array}{c}-0.001 \\
(0.000)\end{array}$ & $\begin{array}{c}0.000 \\
(0.000)\end{array}$ \\
\hline Constant & $\mathrm{NA}$ & NA & $\begin{array}{l}-0.100 \\
(0.070)\end{array}$ & $\begin{array}{l}-0.065 \\
(0.051)\end{array}$ & NA & NA & NA & \\
\hline$R^{2}$ & 0.305 & 0.004 & 0.161 & 0.000 & 0.776 & 0.328 & 0.072 & 0.000 \\
\hline $\mathrm{N}$ & 23 & 23 & 23 & 23 & 23 & 23 & 23 & 23 \\
\hline
\end{tabular}

Note: Dependent variable: Change in return to either university or technical education by state. Variables used in the estimation of returns to university and technical education by state are the same as in all other previous regressions.

significant at $10 \% ; * *$ significant at $5 \% ; * * *$ significant at $1 \%$, 
the ratio of Mission Sucre students in a state to high school enrollment in that state. Columns (1) and (2) focus on the comparison of results between the first semester of 2007 and 2008. Columns (3)-(6) focus on the longer term analysis between 2002 and 2008, and columns (7) and (8) serve as support for the choice of the first semester of 2007 as a pre-treatment period and also as a robustness check.

The results in Table 6 confirm our earlier results, though they are noisier than our difference in difference results 26 Column (1) suggests that with all three proxies, an increase in the percentage of Mission Sucre student enrollment led to a higher decrease in returns to university education in 2008 and hence a more negative difference in returns between the first semester of 2007 and 2008. Focusing on Panel A, our results suggest that a 1\% increase in the share of Mission Sucre students in a state's population led to a decline of 5.2 percentage points in returns to university education between 2007 and 2008. In contrast, we see no impact on returns to technical education, the control group. Similarly, using the second proxy, our results suggest that a $1 \%$ increase in the share of Mission Sucre students among students above the age of 15 in a state led to a decrease of 0.4 percentage points in the returns to university education. With our third proxy we find that a $1 \%$ increase in the share of Mission Sucre students among high school enrollment led to a decline of one percentage point in the returns to university education. In contrast, the impact of Mission Sucre on changes in returns to technical education is again zero under both alternative proxies. Although each of the proxies leads to a different estimate, the inference is consistent: a higher share of Mission Sucre students led to a greater decline in returns to university education.

The results for the longer term analysis are summarized in columns (3)-(6). The constant coefficient is significant using proxy 2 for both the technical and university levels, but insignificant under the other two proxies for both levels. This finding suggests that it is possible that even without any Mission Sucre enrollment impact, returns to university education would still have dropped over the period. Nonetheless, the lack of significance using the other two proxies suggests that this result might not be robust. Focusing on the estimate of $\gamma$, we find with each proxy that it is negative and significant for the university level, and insignificant for the technical level. In addition, the estimates of $\gamma$ under each proxy in columns (1) and (3) are numerically but not statistically different 27 . The

\footnotetext{
${ }^{26}$ A summary of all the data and estimates used in the analysis in Table 6 are in Table A4 and A5 in the appendix.

${ }^{27}$ Proxy 1: -0.056 and -0.082 ; Proxy 2: -0.004 and -0.006 ; Proxy $3:-0.001$ and -0.002
} 
results in columns (5) and (6) assuming no constant are much larger than other estimates, and are the only instance of the impact on the control group being significant. As mentioned above, assuming no constant is unrealistic over the 2002-2008 period and we ignore these estimates 28 As a robustness check, we compare the entire 2007 year to 2008. These estimates are summarized in columns (5) and (6). As mentioned above, the comparison between the entire 2007 year and 2008 may not allow us to properly isolate the impact of the program, which requires a pre-treatment period and a post-treatment period. The second part of 2007 does not make a good pre-treatment period because some Mission Sucre students could have already entered the work force. In this analysis, the sign of the coefficient is still negative, but insignificant and of smaller magnitude. Despite the potential for measurement error in this analysis, since we do not focus on new entrants solely and use a proxy for the share of Mission Sucre in tertiary enrollment states, we find evidence in support of the impact of Mission Sucre. Although we are more cautious of the estimated impact given the measurement issues, our preferred results are in column (1) and (3) using proxy 2.

The results in columns (1)-(4) provide significant evidence of the impact of Mission Sucre on returns to university education for non-Mission Sucre students 29 However, these results also suggest that given the significance of the constant term in Panel B, returns to university education for nonMission Sucre students could have declined between 2002 and 2008 for reasons other than the program.

\section{Inferences, Conclusion and Future Work}

From the beginning of this analysis, our goal has been to document the changes in returns to education in Venezuela, offer explanations for these changes, and provide evidence of the role of Mission Sucre using micro-data.

We start by asking the question of whether returns to education declined in Venezuela between 2002 and 2008. We confirm that average returns, as well as returns to education by levels, decreased

\footnotetext{
${ }^{28}$ However, even when estimates of $\lambda$ are significant for both the technical and university levels, the estimated impact on the returns to university education is much larger than the impact on technical education, regardless of the proxy used.

${ }^{29}$ As mentioned above, we focus on estimating returns for only non-Mission Sucre students. We drop from the sample all individuals who we identify as Mission Sucre students. Individuals who do not indicate the length of their university education and hence cannot be identified as Sucre Mission students remain in our sample only in this analysis.
} 
over this period, with this result being consistent across genders. However, we note quite early that the decline in returns to education across states was nonuniform, which provides the foundation for some of our further analysis.

Our next goal is to explain the fall in returns to tertiary education in Venezuela. We begin by stating our two possible main explanations for this decline and provide a theoretical argument for why Mission Sucre is a more likely explanation. Specifically, an exogenous rise in university enrollment leads to an increase in the supply of skilled labor. Without a matching increase in demand, returns to university education should decline. In addition, possible changes in the quality of university education and the ability distribution of university graduates induced by Mission Sucre could lead to a decrease in returns to university education. We provide evidence of the role of Mission Sucre, focusing solely on the impacts on those who did not pass through the program. One reason why looking at the impact of Mission Sucre on non-participants is useful is that it provides an estimate of the negative externality caused by this policy initiative. Moreover, if we focus on the impact of the program on the sample of all workers we would have to grapple with potential issues of selection into Mission Sucre universities. Hence, our focus on the effect of Mission Sucre on workers with university education who did not pass through the program has multiple advantages. Nonetheless, one limitation to our approach is that our results do not provide evidence of the overall impact of the program on workers in Venezuela or on program participants specifically.

We search for evidence of the impact of Mission Sucre using different techniques, some better than others, but present all of these results to show that there is overwhelming evidence that the decline in returns to education at the university level in Venezuela can be linked with Mission Sucre. We focus on the impact of Mission Sucre on individuals who did not pass through the program because of selection issues that we are unable to resolve. Further, we believe that studying the short-run externalities of such a rapid and far-reaching education expansion program is equally useful. While our main identification strategy relies on a difference in difference analysis, we also present a secondary regression analysis estimating the impact of Mission Sucre enrollment on the decline in returns to education across states. We find that between 2007 and 2008, Mission Sucre led to a 2.7 percentage point decrease in returns to university education for non-Mission Sucre graduates aged 23-28. We also find that a 1\% increase in the share of Mission Sucre students in each state 
led to a 0.4 percentage point decline in the returns to university education for non-Mission Sucre students. We note that this estimate could be downward biased.

Why do these results matter? Falling returns to university education for non-Mission Sucre students may lead to lower demand for college education, which may be detrimental for Venezuela in the long run. Given that Mission Sucre was founded on the premise of welfare improvement yet has created a negative externality on recent graduates who did not participate in the program, it may be necessary to implement alternative polices to mitigate these problems, in particular as the size of the impacts may increase as more Mission Sucre students transition into the labor market. Focusing on ways to grow the demand for skilled labor could be one alternative, but an overhaul of the Mission Sucre program with respect to issues of quality of education and quality of students might also be useful. Studies documenting changes in the supply and demand of skilled labor in Venezuela over this period or directly testing the abilities of university graduates would help identify the appropriate policy intervention. Another question we do not address in this paper is whether the social and private benefits of Mission Sucre exceed the costs of the program, both social and private (including the decline in returns). These are possible areas of future research. We also hope to reexamine the impact of Mission Sucre as additional cohorts of graduates and students from Mission Sucre technical institutions enter the the work force.

\section{Acknowledgement}

This research has received funding from UROP Materials, Supplies, \& Travel Grants for Undergraduate Research at Georgia Institute of Technology. The authors would like to thank Pat Conaway and two anonymous referees for helpful comments and advice. We would also like to thank participants at the International Economics/Economic Development Seminar at the University of North Carolina-Chapel Hill, participants at the Economics seminar series at the Georgia Institute of Technology, and participants at the 2009 International/Development Economics Workshop organized by Mercer University and the Federal Reserve Bank of Atlanta for helpful comments. Of course, all remaining errors are ours. 


\section{References}

Baland, J., \& Francois, P. (2000). Rent-seeking and Resource Booms. Journal of Development Economics, Vol. 61(2): 527-542.

Blom, A., Holm-Nielsen L., \& Verner D. (2001). Education, Earnings and Inequality in Brazil, 198298: Implications for Education Policy. World Bank Policy Research Working Paper 2686, Washington, DC.

D’Elia, Y. \& Cabezas, L.F. (2008). Las Misiones Sociales en Venezuela. Instituto Latinoamericano de Investigaciones Sociales.

D'Elia, Y. (2006). Las Misiones Sociales en Venezuela: una Aproximación a su Comprensión y Análisis. Instituto Latinoamericano de Investigaciones Sociales.

Fiszbein, A., \& Psacharopoulos G. (1993). A Cost-Benefit Analysis of Educational Investment in Venezuela: 1989 Update. Economics of Education Review, Vol. 12(4): 293-298.

Fleisher, B., Peter, K.S., \& Wang X. (2005). Returns to Skills and the Speed of Reforms: Evidence from Central and Eastern Europe, China, and Russia. Journal of Comparative Economics, 33(2): $351-370$.

De la Fuente, A., \& Jimeno F. (2008). The Private and Fiscal Returns to Schooling: A General Framework and Some Results for EU Countries. UFAE and IAE Working Papers 737.08, Unitat de Fonaments de l'Anlisi Econmica (UAB) and Institut d'Anlisi Econmica (CSIC).

Gallagher, M. (1991). Rent-Seeking and Economic Growth in Africa. Westview Press: Boulder.

Gorodnichenko, Y., \& Peter, K.S. (2005). Returns to Schooling in Russia and Ukraine: A Semiparametric Approach to Cross-country Comparative Analysis. Journal of Comparative Economics, 33(2): 324-350.

Hilaire, A. (1992). The Effects of Trinidad and Tobago's Oil Boom on Relative Prices, Wages and Labour Flows. Social and Economic Studies, 41(2): 45-82. 
Hsieh, C., Miguel, E., Ortega D. \& Rodriguez F. (2009). The Price of Political Opposition: Evidence from Venezuela's Maisanta. NBER Working Papers 14923, National Bureau of Economic Research.

Kugler, B. \& Psacharopoulos, G. (1989). Earnings and Education in Argentina: an Analysis of the 1985 Buenos Aires Household Survey. Economics of Education Review, 8(4): 353-365.

Lachler, U. (1998). Education and Earnings Inequality in Mexico. World Bank Policy Research Working Paper 1949, Washington, DC.

Lane, P. \& Tornell, A (1996). Power, Growth, and the Voracity Effect. Journal of Economic Growth, $1(2): 213-41$.

Lane, P. \& Tornell, A. (1999). The Voracity Effect. American Economic Review, 89(1), 22-46.

Mincer, J. (1974). Schooling, Experience and Earnings. National Bureau of Economic Research Books: New York.

Ortega, D. \& Rodrguez F. (2008). Freed from Illiteracy? A Closer Look at Venezuela's Robinson Campaign. Economic Development and Cultural Change, 57(1): 1-30.

Oyelere, R. (2010). Africa's Education Enigma? The Nigerian Story. Journal of Development Economics, 91(1): 128139.

Patrinos, H. \& Sakellariou C. (2006). Economic Volatility and Returns to Education in Venezuela. Applied Economics, 38(17): 1991-2005.

Patrinos, H. A., Ridao-Cano, C. \& Sakellariou. C. (2009). A note on schooling and wage inequality in the public and private sector," Empirical Economics, 37(2): 383-392.

Psacharopoulos, G., \& Alam A. (1991). Earnings and Education in Venezuela: an Update from the 1987 Household Survey. Economics of Education Review, 10(1): 29-36.

Psacharopoulos, G., \& Velez, E. (1992). Schooling, Ability, and Earnings in Colombia. Economic Development and Cultural Change, 40(3): 629-43.

Psacharopoulos, G., \& Steier, F. (1998). Education and the Labor Market in Venezuela, 1975-1984. Economics of Education Review, 7(3): 321-332. 
Psacharopoulos, G., Velez, E., Panagides A. \& Hongyu, Y. (1996). Returns to Education During Economic Boom and Recession: Mexico 1984, 1989 and 1992. Education Economics. 4(3): 219230.

Staiger, D., \& Stock, J. (1997). Instrumental Variable Regression with Weak Instruments. Econometrica, 65(3):557-586.

Uwaifo, R. (2006). Three Essays on the Returns to Education Enigma in Nigeria. University of California Berkeley, PhD Dissertation. 


\section{Appendix}

Figure A1:Trend in Returns to Education over time

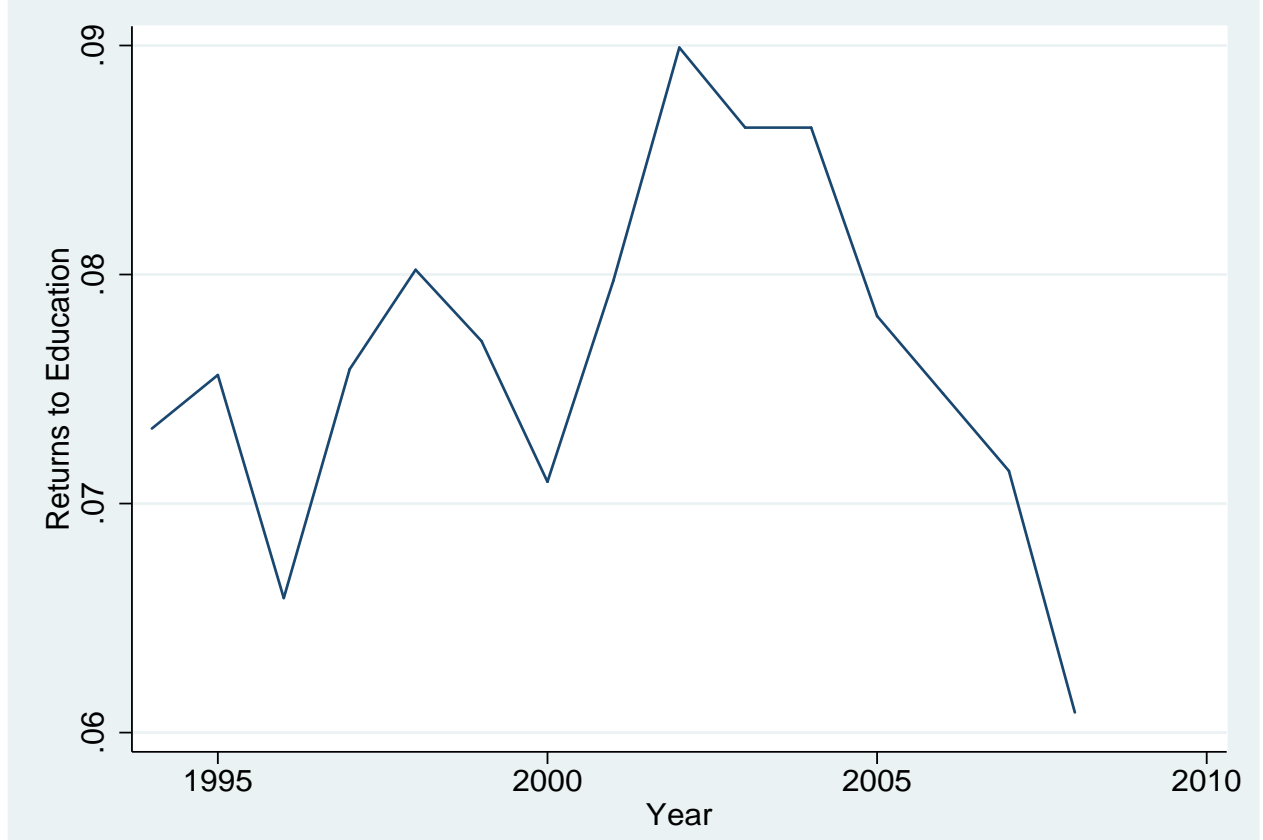

Table A1: Returns to Education Across Latin America

\begin{tabular}{llll}
\hline \hline Country & Year & Return & Source \\
\hline Argentina & 2003 & 11 & Patrinos, Ridao-Cano and Sakellariou (2009) \\
Bolivia & 2002 & 10.3 & Patrinos, Ridao-Cano and Sakellariou (2009) \\
Brazil & 2002 & 15.7 & Patrinos, Ridao-Cano and Sakellariou (2009) \\
Chile & 2003 & 12 & Patrinos, Ridao-Cano and Sakellariou (2009) \\
Colombia & 2003 & 10.4 & Patrinos, Ridao-Cano and Sakellariou (2009) \\
Costa Rica & 1989 & 10.9 & Psacharapoulos et al (1996) \\
Dominican Republic & 1989 & 9.4 & Psacharapoulos et al (1996) \\
Ecuador & 1987 & 10.8 & Psacharapoulos et al (1996) \\
El Salvador & 1990 & 9.7 & Psacharapoulos et al (1996) \\
Guatemala & 2000 & 12.6 & Patrinos, Ridao-Cano and Sakellariou (2009) \\
Honduras & 1989 & 17.6 & Psacharapoulos et al (1996) \\
Mexico & 2002 & 11.3 & Patrinos, Ridao-Cano and Sakellariou (2009) \\
Panama & 1989 & 13.7 & Psacharapoulos et al (1996) \\
Paraguay & 1990 & 11.5 & Psacharapoulos et al (1996) \\
Peru & 1989 & 8.1 & Psacharapoulos et al (1996) \\
Uruguay & 1989 & 9.7 & Psacharapoulos et al (1996) \\
Venezuela & 2002 & 10.4 & Patrinos, Ridao-Cano and Sakellariou (2009) \\
Latin America & 2002 & 11.6 & Patrinos, Ridao-Cano and Sakellariou (2009) \\
\hline \hline
\end{tabular}


Table A2: Basic Regression: Estimating Return to Years of Schooling by Gender 2002 vs 2008

\begin{tabular}{|c|c|c|c|c|c|c|c|c|}
\hline & \multicolumn{4}{|c|}{2002} & \multicolumn{4}{|c|}{2008} \\
\hline & \multicolumn{2}{|c|}{ Men } & \multicolumn{2}{|c|}{ Women } & \multicolumn{2}{|c|}{ Men } & \multicolumn{2}{|c|}{ Women } \\
\hline & (1) & $(2)$ & $(3)$ & (4) & $(5)$ & $(6)$ & (7) & $(8)$ \\
\hline Years of schooling & $\begin{array}{c}0.076^{* * *} \\
(0.001)\end{array}$ & $\begin{array}{c}0.073^{* * *} \\
(0.001)\end{array}$ & $\begin{array}{c}0.111^{* * *} \\
(0.001)\end{array}$ & $\begin{array}{c}0.092^{* * *} \\
(0.001)\end{array}$ & $\begin{array}{c}0.051^{* * *} \\
(0.001)\end{array}$ & $\begin{array}{c}0.051^{* * *} \\
(0.001)\end{array}$ & $\begin{array}{c}0.076^{* * *} \\
(0.001)\end{array}$ & $\begin{array}{c}0.067^{* * *} \\
(0.001)\end{array}$ \\
\hline Age & $\begin{array}{c}0.097^{* * *} \\
(0.004)\end{array}$ & $\begin{array}{c}0.063^{* * *} \\
(0.004)\end{array}$ & $\begin{array}{c}0.067^{* * *} \\
(0.006)\end{array}$ & $\begin{array}{c}0.037^{* * *} \\
(0.006)\end{array}$ & $\begin{array}{c}0.051^{* * *} \\
(0.004)\end{array}$ & $\begin{array}{c}0.030^{* * *} \\
(0.004)\end{array}$ & $\begin{array}{c}0.039 * * * \\
(0.005)\end{array}$ & $\begin{array}{c}0.023^{* * *} \\
(0.006)\end{array}$ \\
\hline$A g e^{2}$ & $\begin{array}{c}-0.001^{* * *} \\
(0.000)\end{array}$ & $\begin{array}{c}-0.001^{* * *} \\
(0.000)\end{array}$ & $\begin{array}{c}-0.001 * * * \\
(0.000)\end{array}$ & $\begin{array}{c}-0.000 * * * \\
(0.000)\end{array}$ & $\begin{array}{c}-0.001^{* * *} \\
(0.000)\end{array}$ & $\begin{array}{c}-0.000^{* * *} \\
(0.000)\end{array}$ & $\begin{array}{c}-0.000^{* * *} \\
(0.000)\end{array}$ & $\begin{array}{l}-0.000^{*} \\
(0.000)\end{array}$ \\
\hline States & yes & yes & yes & yes & yes & yes & yes & yes \\
\hline Cohorts & yes & yes & yes & yes & yes & yes & yes & yes \\
\hline $\mathrm{N}$ & 47534 & 45007 & 31660 & 28715 & 36215 & 36215 & 24374 & 24374 \\
\hline$R^{2}$ & 0.287 & 0.244 & 0.300 & 0.235 & 0.236 & 0.185 & 0.262 & 0.176 \\
\hline $\begin{array}{c}\text { Years of schooling } \\
\text { (Sucre dropped) }\end{array}$ & $\begin{array}{c}0.076^{* * *} \\
(0.001)\end{array}$ & $\begin{array}{c}0.073^{* * *} \\
(0.001)\end{array}$ & $\begin{array}{c}0.111^{* * *} \\
(0.001)\end{array}$ & $\begin{array}{c}0.092^{* * *} \\
(0.001)\end{array}$ & $\begin{array}{c}0.051^{* * *} \\
(0.001)\end{array}$ & $\begin{array}{c}0.051^{* * *} \\
(0.001)\end{array}$ & $\begin{array}{c}0.076^{* * *} \\
(0.001)\end{array}$ & $\begin{array}{c}0.067^{* * *} \\
(0.001)\end{array}$ \\
\hline $\mathrm{N}$ & 47520 & 44993 & 31630 & 28689 & 36184 & 36184 & 24332 & 24332 \\
\hline$R^{2}$ & 0.287 & 0.244 & 0.300 & 0.235 & 0.236 & 0.185 & 0.262 & 0.175 \\
\hline
\end{tabular}

Note: Dependent variable in columns (1), (3), (5) and (7) is log of monthly income; (2), (4), (6) and $(8)$ are on $\log$ of hourly wage as a robustness check. ${ }^{*}$ significant at $10 \%$; ${ }^{* *}$ significant at $5 \%$; $* * *$ significant at $1 \%$. 
Table A3: Basic Regression: Average Return to Education by States, 2002-2008

\begin{tabular}{|c|c|c|c|c|}
\hline & 2002 & 2003 & 2007 & 2008 \\
\hline Federal District & $\begin{array}{c}0.073^{* * *} \\
(0.003)\end{array}$ & $\begin{array}{c}0.067^{* * *} \\
(0.003)\end{array}$ & $\begin{array}{c}0.075^{* * *} \\
(0.003)\end{array}$ & $\begin{array}{c}0.063^{* * *} \\
(0.003)\end{array}$ \\
\hline Amazonas & $\begin{array}{c}0.114^{* * *} \\
(0.006)\end{array}$ & $\begin{array}{c}0.123^{* * *} \\
(0.006)\end{array}$ & $\begin{array}{c}0.084^{* * *} \\
(0.004)\end{array}$ & $\begin{array}{c}0.077^{* * *} \\
(0.004)\end{array}$ \\
\hline Anzoategui & $\begin{array}{c}0.097^{* * *} \\
(0.005)\end{array}$ & $\begin{array}{c}0.083^{* * *} \\
(0.004)\end{array}$ & $\begin{array}{c}0.054^{* * *} \\
(0.004)\end{array}$ & $\begin{array}{c}0.043^{* * *} \\
(0.004)\end{array}$ \\
\hline Apure & $\begin{array}{c}0.093^{* * *} \\
(0.004)\end{array}$ & $\begin{array}{c}0.094^{* * *} \\
(0.005)\end{array}$ & $\begin{array}{c}0.067^{* * *} \\
(0.003)\end{array}$ & $\begin{array}{c}0.053^{* * *} \\
(0.003)\end{array}$ \\
\hline Aragua & $\begin{array}{c}0.087^{* * * *} \\
(0.004)\end{array}$ & $\begin{array}{c}0.086^{* * *} \\
(0.003)\end{array}$ & $\begin{array}{c}0.057^{* * *} * \\
(0.005)\end{array}$ & $\begin{array}{c}0.047^{* * *} \\
(0.004)\end{array}$ \\
\hline Barinas & $\begin{array}{c}0.108^{* * *} \\
(0.004)\end{array}$ & $\begin{array}{c}0.102^{* * *} \\
(0.004)\end{array}$ & $\begin{array}{c}0.073^{* * *} \\
(0.003)\end{array}$ & $\begin{array}{c}0.062^{* * *} \\
(0.003)\end{array}$ \\
\hline Bolivar & $\begin{array}{c}0.094^{* * *} \\
(0.004)\end{array}$ & $\begin{array}{c}0.090^{* * *} \\
(0.004)\end{array}$ & $\begin{array}{c}0.085^{* * *} \\
(0.004)\end{array}$ & $\begin{array}{c}0.064^{* * *} \\
(0.004)\end{array}$ \\
\hline Carabobo & $\begin{array}{c}0.091^{* * *} \\
(0.003)\end{array}$ & $\begin{array}{c}0.082^{* * *} \\
(0.003)\end{array}$ & $\begin{array}{c}0.076^{* * *} \\
(0.003)\end{array}$ & $\begin{array}{c}0.052^{* * *} \\
(0.003)\end{array}$ \\
\hline Cojedes & $\begin{array}{c}0.108^{* * *} * \\
(0.006)\end{array}$ & $\begin{array}{c}0.093^{* * *} \\
(0.005)\end{array}$ & $\begin{array}{c}0.073^{* * *} \\
(0.006)\end{array}$ & $\begin{array}{c}0.058^{* * *} \\
(0.005)\end{array}$ \\
\hline Delta Amacuro & $\begin{array}{c}0.075^{* * *} \\
(0.004)\end{array}$ & $\begin{array}{c}0.063^{* * *} \\
(0.003)\end{array}$ & $\begin{array}{c}0.058^{* * *} \\
(0.005)\end{array}$ & $\begin{array}{c}0.061^{* * *} \\
(0.004)\end{array}$ \\
\hline Falcon & $\begin{array}{c}0.112^{* * *} \\
(0.004)\end{array}$ & $\begin{array}{c}0.108^{* * *} * \\
(0.004)\end{array}$ & $\begin{array}{c}0.090 * * * \\
(0.004)\end{array}$ & $\begin{array}{c}0.068^{* * *} \\
(0.004)\end{array}$ \\
\hline Guarico & $\begin{array}{c}0.074^{* * *} * \\
(0.004)\end{array}$ & $\begin{array}{c}0.078^{* * *} * \\
(0.005)\end{array}$ & $\begin{array}{c}0.062^{* * *} \\
(0.004)\end{array}$ & $\begin{array}{c}0.056^{* * *} \\
(0.004)\end{array}$ \\
\hline Lara & $\begin{array}{c}0.086^{* * *} \\
(0.003)\end{array}$ & $\begin{array}{c}0.084^{* * *} * \\
(0.002)\end{array}$ & $\begin{array}{c}0.073^{* * *} \\
(0.002)\end{array}$ & $\begin{array}{c}0.060^{* * *} \\
(0.002)\end{array}$ \\
\hline Merida & $\begin{array}{c}0.076^{* * *} \\
(0.003)\end{array}$ & $\begin{array}{c}0.072^{* * *} \\
(0.002)\end{array}$ & $\begin{array}{c}0.058^{* * *} \\
(0.002)\end{array}$ & $\begin{array}{c}0.056^{* * *} \\
(0.002)\end{array}$ \\
\hline Miranda & $\begin{array}{c}0.106^{* * *} \\
(0.003)\end{array}$ & $\begin{array}{c}0.104^{* * *} \\
(0.003)\end{array}$ & $\begin{array}{c}0.086^{* * *} \\
(0.003)\end{array}$ & $\begin{array}{c}0.074^{* * *} \\
(0.003)\end{array}$ \\
\hline Monagas & $\begin{array}{c}0.101^{* * *} \\
(0.004)\end{array}$ & $\begin{array}{c}0.098^{* * *} * \\
(0.003)\end{array}$ & $\begin{array}{c}0.087^{* * *} \\
(0.003)\end{array}$ & $\begin{array}{c}0.074^{* * *} \\
(0.003)\end{array}$ \\
\hline Nueva Esparta & $\begin{array}{c}0.104^{* * *} \\
(0.007)\end{array}$ & $\begin{array}{c}0.087^{* * *} \\
(0.006)\end{array}$ & $\begin{array}{c}0.044^{* * *} \\
(0.004)\end{array}$ & $\begin{array}{c}0.049^{* * *} \\
(0.004)\end{array}$ \\
\hline Portuguesa & $\begin{array}{c}0.091^{* * *} * \\
(0.003)\end{array}$ & $\begin{array}{c}0.087^{* * *} * \\
(0.003)\end{array}$ & $\begin{array}{c}0.064^{* * *} * \\
(0.002)\end{array}$ & $\begin{array}{c}0.059^{* * *} \\
(0.003)\end{array}$ \\
\hline Sucre & $\begin{array}{c}0.100^{* * *} * \\
(0.003)\end{array}$ & $\begin{array}{c}0.106^{* * *} \\
(0.003)\end{array}$ & $\begin{array}{c}0.052^{* * *} \\
(0.003)\end{array}$ & $\begin{array}{c}0.053^{* * *} \\
(0.003)\end{array}$ \\
\hline Tachira & $\begin{array}{c}0.095^{* * *} \\
(0.003)\end{array}$ & $\begin{array}{c}0.094^{* * *} \\
(0.003)\end{array}$ & $\begin{array}{c}0.066^{* * *} \\
(0.004)\end{array}$ & $\begin{array}{c}0.059^{* * *} \\
(0.003)\end{array}$ \\
\hline Trujillo & $\begin{array}{c}0.083^{* * *} \\
(0.004)\end{array}$ & $\begin{array}{c}0.074^{* * *} \\
(0.004)\end{array}$ & $\begin{array}{c}0.072^{* * *} \\
(0.003)\end{array}$ & $\begin{array}{c}0.065^{* * *} \\
(0.004)\end{array}$ \\
\hline Yaracuy & $\begin{array}{c}0.090^{* * *} \\
(0.004)\end{array}$ & $\begin{array}{c}0.083^{* * *} \\
(0.004)\end{array}$ & $\begin{array}{c}0.060^{* * *} \\
(0.005)\end{array}$ & $\begin{array}{c}0.055^{* * *} \\
(0.005)\end{array}$ \\
\hline Zulia & $\begin{array}{c}0.077^{* * * *} \\
(0.002)\end{array}$ & $\begin{array}{c}0.073^{* * *} \\
(0.002)\end{array}$ & $\begin{array}{c}0.063^{* * *} \\
(0.002)\end{array}$ & $\begin{array}{c}0.059^{* * *} \\
(0.002)\end{array}$ \\
\hline Vargas & $\begin{array}{c}0.106^{* * *} * \\
(0.008)\end{array}$ & $\begin{array}{c}0.089^{* * *} * \\
(0.006)\end{array}$ & $\begin{array}{c}0.062^{* * *} \\
(0.005)\end{array}$ & $\begin{array}{c}0.054^{* * *} \\
(0.005)\end{array}$ \\
\hline
\end{tabular}

Note: Dependent variable: $\log$ of monthly income ${ }^{*} p<0.05,{ }^{*} p<0.01,{ }^{* * *} p<0.001$ 
Table A4: Wage Equation: Coefficient Estimate For Technical and University Levels by State, 2002-2008

\begin{tabular}{|c|c|c|c|c|c|c|c|c|}
\hline & \multicolumn{2}{|c|}{2002} & \multicolumn{2}{|c|}{2003} & \multicolumn{2}{|c|}{2007} & \multicolumn{2}{|c|}{2008} \\
\hline & Technical & University & Technical & Technical & Technical & University & Technical & University \\
\hline & $(1)$ & $(2)$ & $(3)$ & $(4)$ & $(5)$ & $(6)$ & (7) & $(8)$ \\
\hline \multirow[t]{2}{*}{ Federal District } & $0.394^{* * *}$ & $0.619^{* * *}$ & $0.247^{* * *}$ & $0.630^{* * *}$ & $0.195^{* * *}$ & $0.597^{* * *}$ & $0.308^{* * *}$ & $0.497 * * *$ \\
\hline & $(0.038)$ & $(0.041)$ & $(0.040)$ & $(0.037)$ & $(0.032)$ & $(0.037)$ & $(0.033)$ & $(0.034)$ \\
\hline \multirow[t]{2}{*}{ Amazonas } & $0.405^{* * *}$ & $0.797^{* * *}$ & $0.234^{*}$ & $0.690^{* * *}$ & $0.324^{* * *}$ & $0.613^{* * *}$ & $0.285^{* *}$ & $0.651^{* * *}$ \\
\hline & $(0.085)$ & $(0.079)$ & $(0.119)$ & $(0.080)$ & $(0.073)$ & $(0.045)$ & $(0.100)$ & $(0.052)$ \\
\hline \multirow[t]{2}{*}{ Anzoategui } & $0.391 * * *$ & $0.762^{* * *}$ & $0.528 * * *$ & $0.768^{* * *}$ & $0.311^{* * *}$ & $0.482^{* * *}$ & $0.268^{* * *}$ & $0.489 * * *$ \\
\hline & $(0.079)$ & $(0.062)$ & $(0.061)$ & $(0.057)$ & $(0.046)$ & $(0.051)$ & $(0.047)$ & $(0.072)$ \\
\hline \multirow[t]{2}{*}{ Apure } & $0.438 * * *$ & $0.893^{* * *}$ & $0.389^{* *}$ & $0.876^{* * *}$ & $0.416^{* * *}$ & $0.664^{* * *}$ & $0.442^{* * *}$ & $0.696^{* * *}$ \\
\hline & $(0.093)$ & $(0.076)$ & $(0.130)$ & $(0.084)$ & $(0.070)$ & $(0.047)$ & $(0.087)$ & $(0.047)$ \\
\hline \multirow[t]{2}{*}{ Aragua } & $0.368 * * *$ & $0.736^{* * *}$ & $0.388^{* * *}$ & $0.775^{* * *}$ & $0.178^{* * *}$ & 0.134 & $0.185^{* * *}$ & $0.446^{* * *}$ \\
\hline & $(0.047)$ & $(0.050)$ & $(0.045)$ & $(0.046)$ & $(0.048)$ & $(0.241)$ & $(0.045)$ & $(0.079)$ \\
\hline \multirow[t]{2}{*}{ Barinas } & $0.435^{* * *}$ & $0.845^{* * *}$ & $0.374^{* * *}$ & $0.883^{* * *}$ & $0.408^{* * *}$ & $0.607^{* * *}$ & $0.295^{* * *}$ & $0.487 * * *$ \\
\hline & $(0.076)$ & $(0.068)$ & $(0.071)$ & $(0.061)$ & $(0.057)$ & $(0.050)$ & $(0.060)$ & $(0.046)$ \\
\hline \multirow[t]{2}{*}{ Bolivar } & $0.362^{* * *}$ & $0.756^{* * *}$ & $0.308^{* * *}$ & $0.730 * * *$ & $0.246^{* * *}$ & $0.715^{* * *}$ & $0.395^{* * *}$ & $0.642^{* * *}$ \\
\hline & $(0.056)$ & $(0.051)$ & $(0.051)$ & $(0.057)$ & $(0.048)$ & $(0.042)$ & $(0.049)$ & $(0.046)$ \\
\hline \multirow{2}{*}{ Carabobo } & $0.344^{* * *}$ & $0.737 * * *$ & $0.285^{* * *}$ & $0.711^{* * *}$ & $0.297^{* * *}$ & $0.570 * * *$ & $0.266^{* * *}$ & $0.516^{* * *}$ \\
\hline & $(0.039)$ & $(0.042)$ & $(0.043)$ & $(0.037)$ & $(0.041)$ & $(0.045)$ & $(0.040)$ & $(0.037)$ \\
\hline \multirow[t]{2}{*}{ Cojedes } & $0.536^{* * *}$ & $0.994^{* * *}$ & $0.350 * * *$ & $0.780 * * *$ & $0.359^{* * *}$ & $0.689 * * *$ & $0.332^{* * *}$ & $0.533^{* * *}$ \\
\hline & $(0.082)$ & $(0.066)$ & $(0.100)$ & $(0.066)$ & $(0.080)$ & $(0.073)$ & $(0.076)$ & $(0.079)$ \\
\hline \multirow[t]{2}{*}{ Delta Amacuro } & $0.304^{* * *}$ & $0.585^{* * *}$ & $0.410^{* * *}$ & $0.791^{* * *}$ & $0.253^{* * *}$ & $0.405^{* * *}$ & $0.190 * * *$ & $0.408^{* * *}$ \\
\hline & $(0.055)$ & $(0.066)$ & $(0.040)$ & $(0.057)$ & $(0.068)$ & $(0.054)$ & $(0.041)$ & $(0.047)$ \\
\hline \multirow[t]{2}{*}{ Falcon } & $0.419^{* * *}$ & $1.009 * * *$ & $0.384^{* * *}$ & $0.955^{* * *}$ & $0.438^{* * *}$ & $0.760^{* * *}$ & $0.308^{* * *}$ & $0.641^{* * *}$ \\
\hline & $(0.073)$ & $(0.053)$ & $(0.089)$ & $(0.059)$ & $(0.052)$ & $(0.042)$ & $(0.062)$ & $(0.046)$ \\
\hline \multirow[t]{2}{*}{ Guarico } & $0.375^{* * *}$ & $0.964^{* * *}$ & $0.525^{* * *}$ & $0.770 * * *$ & $0.393^{* * *}$ & $0.745^{* * *}$ & $0.308^{* * *}$ & $0.640 * * *$ \\
\hline & $(0.113)$ & $(0.081)$ & $(0.093)$ & $(0.078)$ & $(0.085)$ & $(0.059)$ & $(0.081)$ & $(0.058)$ \\
\hline \multirow[t]{2}{*}{ Lara } & $0.356^{* * *}$ & $0.809 * * *$ & $0.319 * * *$ & $0.780^{* * *}$ & $0.418^{* * *}$ & $0.694^{* * *}$ & $0.309^{* * *}$ & $0.624^{* * *}$ \\
\hline & $(0.061)$ & $(0.046)$ & $(0.055)$ & $(0.041)$ & $(0.032)$ & $(0.027)$ & $(0.032)$ & $(0.030)$ \\
\hline \multirow[t]{2}{*}{ Merida } & $0.271^{* * *}$ & $0.738^{* * *}$ & $0.332^{* * *}$ & $0.700^{* * *}$ & $0.191^{* * *}$ & $0.566^{* * *}$ & $0.295^{* * *}$ & $0.576^{* * *}$ \\
\hline & $(0.057)$ & $(0.043)$ & $(0.053)$ & $(0.038)$ & $(0.049)$ & $(0.036)$ & $(0.051)$ & $(0.033)$ \\
\hline \multirow[t]{2}{*}{ Miranda } & $0.388 * * *$ & $0.719^{* * *}$ & $0.346^{* * *}$ & $0.752^{* * *}$ & $0.282^{* * *}$ & $0.756^{* * *}$ & $0.209^{* * *}$ & $0.584 * * *$ \\
\hline & $(0.039)$ & $(0.036)$ & $(0.047)$ & $(0.036)$ & $(0.029)$ & $(0.036)$ & $(0.036)$ & $(0.034)$ \\
\hline Monagas & $0.417^{* * *}$ & $0.809 * * *$ & $0.413^{* * *}$ & $0.922^{* * *}$ & $0.314^{* * *}$ & $0.585^{* * *}$ & $0.384^{* * *}$ & $0.550 * * *$ \\
\hline & $(0.067)$ & $(0.066)$ & $(0.087)$ & $(0.052)$ & $(0.074)$ & $(0.042)$ & $(0.062)$ & $(0.049)$ \\
\hline Nueva Esparta & $0.487 * * *$ & $0.692^{* * *}$ & $0.265^{* * *}$ & $0.726^{* * *}$ & 0.112 & $0.436^{* * *}$ & $0.211^{* *}$ & $0.526 * * *$ \\
\hline & $(0.072)$ & $(0.097)$ & $(0.074)$ & $(0.089)$ & $(0.059)$ & $(0.054)$ & $(0.077)$ & $(0.056)$ \\
\hline Portuguesa & $0.391^{* * *}$ & $0.874^{* * *}$ & $0.325^{* * *}$ & $0.818^{* * *}$ & $0.352^{* * *}$ & $0.599 * * *$ & $0.401^{* * *}$ & $0.676^{* * *}$ \\
\hline & $(0.065)$ & $(0.059)$ & $(0.071)$ & $(0.054)$ & $(0.043)$ & $(0.034)$ & $(0.045)$ & $(0.043)$ \\
\hline Sucre & $0.193^{* *}$ & $0.826^{* * *}$ & $0.206^{* *}$ & $0.614^{* * *}$ & $0.347^{* * *}$ & $0.764^{* * *}$ & $0.279^{* * *}$ & $0.699 * * *$ \\
\hline & $(0.072)$ & $(0.049)$ & $(0.074)$ & $(0.054)$ & $(0.074)$ & $(0.053)$ & $(0.064)$ & $(0.045)$ \\
\hline Tachira & $0.471^{* * *}$ & $0.956^{* * *}$ & $0.361^{* * *}$ & $0.896^{* * *}$ & $0.245^{* * *}$ & $0.645^{* * *}$ & $0.260^{* * *}$ & $0.531^{* * *}$ \\
\hline & $(0.053)$ & $(0.047)$ & $(0.052)$ & $(0.046)$ & $(0.051)$ & $(0.054)$ & $(0.049)$ & $(0.058)$ \\
\hline Trujillo & $0.323^{* * *}$ & $0.773^{* * *}$ & $0.422^{* * *}$ & $0.806^{* * *}$ & $0.218^{* * *}$ & $0.626^{* * *}$ & $0.359^{* * *}$ & $0.687^{* * *}$ \\
\hline & $(0.068)$ & $(0.060)$ & $(0.065)$ & $(0.053)$ & $(0.063)$ & $(0.043)$ & $(0.054)$ & $(0.052)$ \\
\hline Yaracuy & $0.452^{* * *}$ & $0.952^{* * *}$ & $0.380^{* * *}$ & $0.924^{* * *}$ & $0.231^{* * *}$ & $0.521^{* * *}$ & $0.272^{* * *}$ & $0.511^{* * *}$ \\
\hline & $(0.063)$ & $(0.050)$ & $(0.074)$ & $(0.059)$ & $(0.063)$ & $(0.075)$ & $(0.055)$ & $(0.056)$ \\
\hline Zulia & $0.381^{* * *}$ & $0.824^{* * *}$ & $0.406^{* * *}$ & $0.801^{* * *}$ & $0.297^{* * *}$ & $0.631^{* * *}$ & $0.286^{* * *}$ & $0.595^{* * *}$ \\
\hline & $(0.050)$ & $(0.040)$ & $(0.053)$ & $(0.044)$ & $(0.041)$ & $(0.034)$ & $(0.038)$ & $(0.037)$ \\
\hline Vargas & $0.355^{* * *}$ & $0.737^{* * *}$ & $0.273^{* * *}$ & $0.705^{* * *}$ & $0.334^{* * *}$ & $0.511^{* * *}$ & $0.326^{* * *}$ & $0.518^{* * *}$ \\
\hline & $(0.070)$ & $(0.069)$ & $(0.082)$ & $(0.086)$ & $(0.055)$ & $(0.072)$ & $(0.047)$ & $(0.063)$ \\
\hline
\end{tabular}

Note: Dependent variable: log of monthly income. *significant at $10 \%$; ${ }^{*}$ significant at $5 \%$; *** significant at $1 \%$. 
Table A5: Data for Basic Regression: Sucre Mission Share and Differences in Returns to Higher Education by State

\begin{tabular}{|c|c|c|c|c|c|c|c|c|c|c|c|}
\hline State & $\begin{array}{l}\text { Total } \\
\text { Pop }\end{array}$ & $\begin{array}{c}\text { Students } \\
>15\end{array}$ & $\begin{array}{c}\text { HS } \\
\text { Students }\end{array}$ & $\begin{array}{l}\text { Sucre } \\
\text { Enroll }\end{array}$ & $\begin{array}{l}\text { \% Sucre } \\
\text { by Pop } \\
\text { by Pop }\end{array}$ & $\begin{array}{c}\% \text { Sucre } \\
\text { by Students } \\
>15\end{array}$ & $\begin{array}{l}\text { \% Sucre } \\
\text { by HS } \\
\text { Students }\end{array}$ & $\begin{array}{l}\text { RTTE } \\
{[08-02]}\end{array}$ & $\begin{array}{l}\text { RTUE } \\
{[08-02]}\end{array}$ & $\begin{array}{c}\text { RTTE } \\
{[08-07 / 1]}\end{array}$ & $\begin{array}{c}\text { RTUE } \\
{[08-07 / 1]}\end{array}$ \\
\hline $\begin{array}{l}\text { Federal } \\
\text { District }\end{array}$ & 2085488 & 135642 & 46629 & 13768 & 0.660 & 10.150 & 29.527 & -0.085 & -0.122 & 0.129 & 0.086 \\
\hline Amazonas & 142220 & & 3696 & 2391 & 1.681 & & 64.692 & -0.120 & -0.146 & -0.159 & 0.024 \\
\hline Anzoategui & 1477926 & 107097 & 36491 & 16431 & 1.112 & 15.342 & 45.028 & -0.092 & -0.239 & -0.184 & -0.053 \\
\hline Apure & 473941 & 19716 & 12704 & 7229 & 1.525 & 36.666 & 56.903 & 0.003 & -0.197 & 0.062 & -0.073 \\
\hline Aragua & 1665247 & 132765 & 50350 & 21448 & 1.288 & 16.155 & 42.598 & -0.052 & -0.077 & 0.134 & -0.128 \\
\hline Barinas & 756581 & 71269 & 20285 & 2968 & 0.392 & 4.165 & 14.632 & -0.141 & -0.358 & -0.165 & -0.128 \\
\hline Bolivar & 1534825 & 157407 & 41587 & 18751 & 1.222 & 11.912 & 45.089 & 0.038 & -0.100 & 0.067 & -0.186 \\
\hline Carabobo & 2226982 & 175539 & 62801 & 20499 & 0.920 & 11.678 & 32.641 & -0.063 & -0.197 & -0.041 & -0.048 \\
\hline Cojedes & 300288 & 24129 & 8300 & 9172 & 3.054 & 38.012 & 110.506 & -0.200 & -0.468 & -0.092 & -0.068 \\
\hline Delta & 152679 & 13379 & 3538 & 1240 & 0.812 & 9.268 & 35.048 & -0.061 & -0.088 & 0.041 & 0.072 \\
\hline \multicolumn{12}{|l|}{ Amacuro } \\
\hline Falcon & 901518 & 71546 & 25740 & 13525 & 1.500 & 18.904 & 52.545 & -0.111 & -0.373 & -0.318 & -0.286 \\
\hline Guarico & 745124 & 39786 & 18783 & 14180 & 1.903 & 35.641 & 75.494 & -0.023 & -0.334 & -0.143 & -0.151 \\
\hline Lara & 1795069 & 153045 & 43976 & 17463 & 0.973 & 11.410 & 39.710 & -0.047 & -0.185 & -0.103 & -0.102 \\
\hline Merida & 843830 & 79593 & 25290 & 17492 & 2.073 & 21.977 & 69.166 & 0.048 & -0.133 & -0.005 & -0.029 \\
\hline Miranda & 2857943 & 235467 & 65591 & 18939 & 0.663 & 8.043 & 28.874 & -0.037 & -0.027 & -0.071 & 0.019 \\
\hline Monagas & 855322 & 73561 & 22190 & 18515 & 2.165 & 25.170 & 83.438 & -0.033 & -0.259 & 0.266 & -0.178 \\
\hline $\begin{array}{l}\text { Nueva } \\
\text { Esparta }\end{array}$ & 436944 & 39706 & 11443 & 4291 & 0.982 & 10.807 & 37.499 & -0.277 & -0.176 & 0.068 & 0.116 \\
\hline Portuguesa & 873375 & 77635 & 21309 & 10116 & 1.158 & 13.030 & 47.473 & 0.009 & -0.199 & 0.068 & 0.088 \\
\hline Sucre & 916646 & 82780 & 24519 & 11171 & 1.219 & 13.495 & 45.561 & 0.086 & -0.127 & -0.151 & -0.242 \\
\hline Tachira & 1177255 & 84663 & 35763 & 13589 & 1.154 & 16.051 & 37.997 & -0.149 & -0.335 & 0.191 & -0.089 \\
\hline Trujillo & 711392 & 48547 & 19284 & 7138 & 1.003 & 14.703 & 37.015 & 0.036 & -0.086 & 0.073 & -0.010 \\
\hline Yaracuy & 597721 & 47336 & 16465 & 7762 & 1.299 & 16.398 & 47.142 & -0.179 & -0.443 & 0.081 & -0.230 \\
\hline Zulia & 3620189 & 264381 & 88851 & 30357 & 0.839 & 11.482 & 34.166 & -0.091 & -0.234 & 0.092 & 0.058 \\
\hline Total & 27148505 & 2134989 & 705585 & 298435 & & & & & & & \\
\hline
\end{tabular}

Note: Dependent variable: $\log$ of monthly income. *significant at $10 \%$; ** significant at $5 \%$; *** significant at $1 \%$. Note: Total pop- Population in the state RTTE [08-02] - difference in return to technical education between 2002 and 2008.

RTUE [08-02] - Difference in return to university education between 2002 and 2008.

RTTE [08-07/1] - difference in return to technical education between 2007 (first half) and 2008.

RTUE [08-07/1] - Difference in return to university education between 2007 (first half) and 2008. 